Review

\title{
Neuroprotective Effects and Therapeutic Potential of Transcorneal Electrical Stimulation for Depression
}

\author{
Wing-Shan Yu ${ }^{1} \oplus$, So-Hyun Kwon ${ }^{1}$, Stephen Kugbere Agadagba ${ }^{2} \oplus$, Leanne-Lai-Hang Chan ${ }^{2}$, \\ Kah-Hui Wong ${ }^{1,3}$ (D) and Lee-Wei Lim ${ }^{1, *(D)}$ \\ 1 Neuromodulation Laboratory, School of Biomedical Sciences, Li Ka Shing Faculty of Medicine, The University \\ of Hong Kong, Hong Kong, China; yuwsw@connect.hku.hk (W.-S.Y.); u3544616@connect.hku.hk (S.-H.K.); \\ wkahhui@um.edu.my (K.-H.W.) \\ 2 Department of Electrical Engineering, City University of Hong Kong, Hong Kong, China; \\ sagadagba3-c@my.cityu.edu.hk (S.K.A.); leanne.chan@cityu.edu.hk (L.-L.-H.C.) \\ 3 Department of Anatomy, Faculty of Medicine, Universiti Malaya, Kuala Lumpur 50603, Malaysia \\ * Correspondence: drlimleewei@gmail.com
}

Citation: Yu, W.-S.; Kwon, S.-H.; Agadagba, S.K.; Chan, L.-L.-H.; Wong, K.-H.; Lim, L.-W. Neuroprotective Effects and Therapeutic Potential of Transcorneal Electrical Stimulation for Depression. Cells 2021, 10, 2492. https://doi.org/10.3390/cells10092492

Academic Editor: Cord Brakebusch

Received: 30 July 2021

Accepted: 17 September 2021

Published: 21 September 2021

Publisher's Note: MDPI stays neutral with regard to jurisdictional claims in published maps and institutional affiliations.

Copyright: (c) 2021 by the authors. Licensee MDPI, Basel, Switzerland. This article is an open access article distributed under the terms and conditions of the Creative Commons Attribution (CC BY) license (https:/ / creativecommons.org/licenses/by/ $4.0 /)$.

\begin{abstract}
Transcorneal electrical stimulation (TES) has emerged as a non-invasive neuromodulation approach that exerts neuroprotection via diverse mechanisms, including neurotrophic, neuroplastic, anti-inflammatory, anti-apoptotic, anti-glutamatergic, and vasodilation mechanisms. Although current studies of TES have mainly focused on its applications in ophthalmology, several lines of evidence point towards its putative use in treating depression. Apart from stimulating visual-related structures and promoting visual restoration, TES has also been shown to activate brain regions that are involved in mood alterations and can induce antidepressant-like behaviour in animals. The beneficial effects of TES in depression were further supported by its shared mechanisms with FDAapproved antidepressant treatments, including its neuroprotective properties against apoptosis and inflammation, and its ability to enhance the neurotrophic expression. This article critically reviews the current findings on the neuroprotective effects of TES and provides evidence to support our hypothesis that TES possesses antidepressant effects.
\end{abstract}

Keywords: TES; transcorneal electrical stimulation; neuromodulation; depression; antidepressant; neuroprotection

\section{Introduction}

Major depressive disorder, commonly known as depression, is the leading cause of disability worldwide [1]. It is considered a major global disease burden, with more than $4.4 \%$ of the world's population estimated to suffer from depression, and 800,000 depressionrelated suicide cases annually [2]. The economic cost of depression in US adults exceeded USD 300 billion in 2018 [3]. According to the Diagnostic and Statistical Manual of Mental Disorders 5th Edition (DSM-V), depression is primarily characterized by anhedonia and sadness persisting for at least 2 weeks, which is accompanied by secondary symptoms such as fatigue, sense of worthlessness, psychomotor agitation, changes in appetite or weight, sleep difficulties, loss of concentration, and/or recurrent thoughts of suicide [4]. The burden of depression is further compounded by the high comorbidity of physical disorders [5], as evidenced by its close association with pain [6,7], dementia [8], type 2 diabetes [9,10], cardiovascular diseases [11-14], and cancers [15]. Depression not only leads to additional medical and financial costs, but also aggravates the prognosis or even mortality in diseased populations.

Depression is commonly treated with psychotherapy and medications that generally target the reuptake of neurotransmitters [16]. Nevertheless, up to $60 \%$ of patients inadequately respond to drug treatments, in which approximately $10-30 \%$ of patients develop treatment-resistant depression (TRD) with failure to respond to two or more types 
of antidepressant treatments [17-20]. Electroconvulsive therapy (ECT) is considered a common treatment for TRD and the remission rate is reported at approximately $50 \%$, with nearly half of the patients relapsing within the first year following ECT [21-25]. Given the increasing prevalence of depression and unsatisfactory outcomes of currently available treatments, there is an urgent need to develop alternative therapeutic options for the treatment of depression.

Neuromodulation is a technology which utilizes electrical stimulation to modulate the nervous system functioning [26]. It is emerging as a promising therapeutic approach against various psychiatric and neurological disorders [20]. Among the different types of neuromodulation-based techniques, transcorneal electrical stimulation (TES) is a noninvasive treatment that is reported to improve visual functions in various ophthalmological conditions [27]. Although current studies on TES mostly focus on its use in ophthalmology, TES is also demonstrated to induce neurobehavioural changes including antidepressantlike behaviour in corneally kindled models [28]. Surprisingly, apart from activating the retina and associated downstream visual structures, enhanced activities are additionally reported in the prefrontal cortex (PFC) and parahippocampal gyrus (PHG) following TES application [29-31]. Although the modulation effects of TES in these non-visual brain regions have yet to be confirmed, both PFC and PHG are involved in mood alterations [32], suggesting that TES may have a role in regulating emotion. The potential neuroprotective properties of TES are possibly achieved through regulating neuroplasticity $[30,33]$, neurotrophic expression [34-40], inflammatory responses [39,41-44], apoptosis [36,45-47], glutamate metabolism [48], and retinal blood flow [49,50]. The putative neuroprotective effects of TES on mood control are further supported by its shared mechanisms of action with current antidepressant treatments, including its neuroprotective effects against apoptosis and inflammation, as well as its ability to promote neurotrophic expression. This review aims to discuss the neuromodulation potential of TES as a treatment for depressive disorders and the neuroprotective mechanisms of action that might contribute to the antidepressant-like responses.

\section{Connections between Visual and Emotional Systems}

A visual-emotional connectivity can be established through cortical and subcortical routes, as visual signals are directed to brain regions that are also involved in emotional regulation (Figure 1) [51-57]. In the cortical pathway, visual outputs generated in the retina are first transmitted to the occipital visual cortex via the lateral geniculate nucleus of the thalamus. From the visual cortex, the information is either projected dorsally to the posterior parietal cortex, or ventrally to the inferior temporal cortex, from which they interconnect with the PFC and limbic structures, including the amygdala and hippocampus [51,54-57]. Alternatively, visual information can be conveyed to the thalamic pulvinar through the superior colliculus as a subcortical sensory input to the amygdala [52-54]. Direct and indirect functional interactions among the amygdala, hippocampus, and PFC significantly contribute to the regulation of emotions [56,58]. Given the close functional link between the visual and emotional brain regions, it is unsurprising that growing evidence supports the bidirectional association between visual impairment and depression. It has been reported that ophthalmic patients with various eye diseases have a $25 \%$ overall prevalence of depressive symptoms, which was significantly higher than that in healthy controls [59]. Likewise, a notable increase in the risk of depression in both blind and visually impaired individuals was identified in a national longitudinal study conducted in South Korea [60]. Conversely, depression may also have a negative impact on visual function. Among retinitis pigmentosa (RP) patients, individuals with depressive symptoms had markedly worse subjective visual function and vision-related quality of life irrespective of the severity of the RP disease [61]. These findings were further supported by a national representative study in the US, which found a longitudinal and bidirectional association between visual impairment and symptoms of mental illness [62]. It was reported that patients with impaired vision were 33\% more likely to develop depression, whereas those with 
depressive symptoms had a 37\% increased risk of reporting vision loss in the future. Given the close association between depression and visual impairment, treatments that were intended for ophthalmology disorders may well be effective in ameliorating emotional conditions, and vice versa.

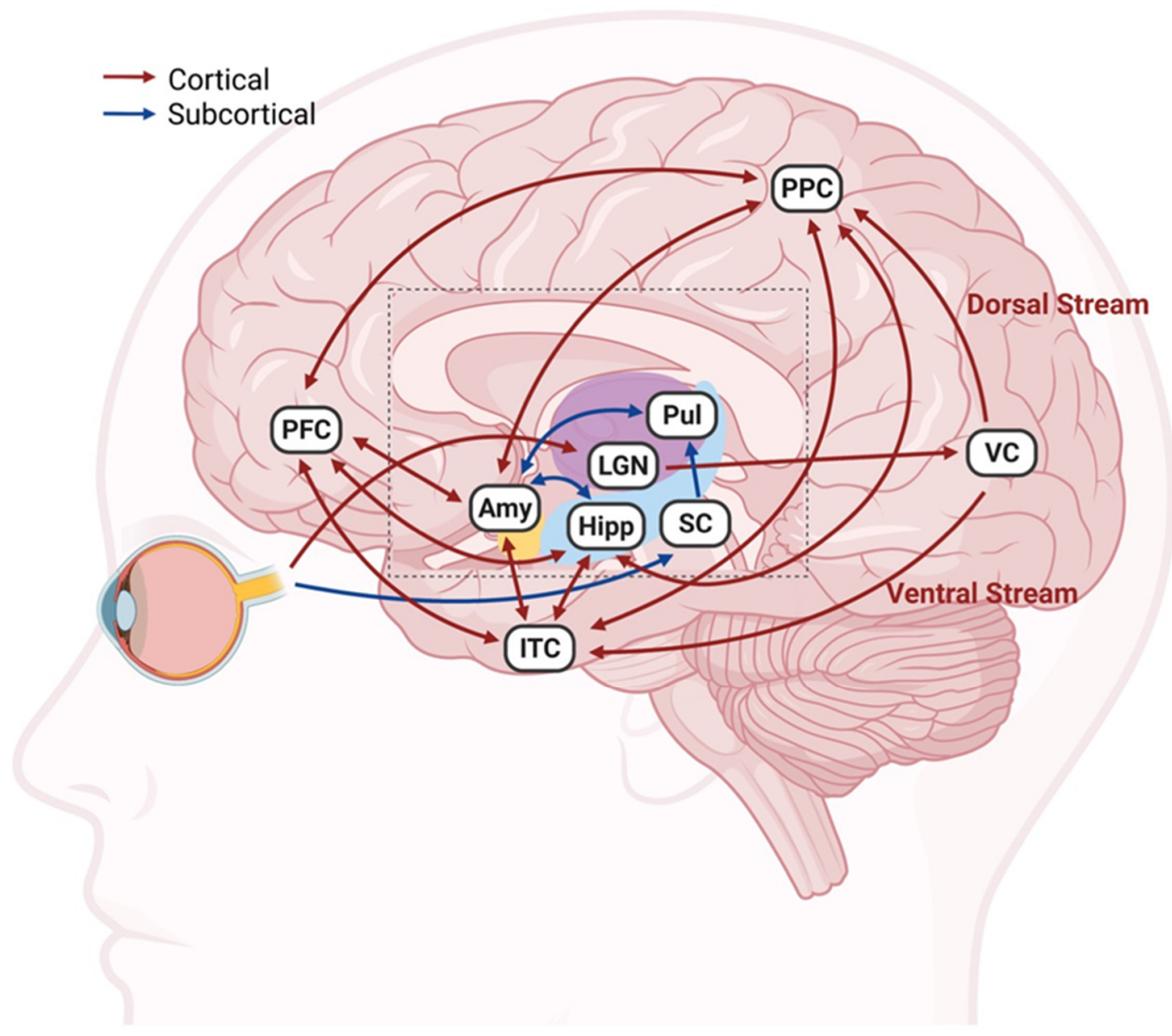

Figure 1. Connections between the visual and emotional systems. The diagram illustrates the major cortical (red arrows) and subcortical (blue arrows) pathways connecting brain regions involved in vision and emotion. In the cortical routes, visual inputs originating from the retina are transmitted to the VC via the thalamic relay station LGN. The VC further projects dorsally to PPC or ventrally to ITC, where they interconnect to the PFC and limbic structures, including Amy and Hipp, which are involved in emotional regulation. Alternatively, visual signals can be conveyed subcortically to Amy via SC and Pul in the thalamus. Amy, Hipp, and PFC can further interchange information directly or indirectly through various relay structures. The less significant intermediate structures and connections in these pathways are not shown to simplify the diagram. Amy: amygdala; Hipp: hippocampus; ITC: inferior temporal cortex; LGN: lateral geniculate nuclei; PFC: prefrontal cortex; PPC: posterior parietal cortex; Pul: pulvinar; SC: superior colliculus; VC: visual cortex. Created with BioRender.com (accessed on 28 August 2021).

\section{Application of TES in Ophthalmology}

Transcorneal electrical stimulation is a non-invasive neuromodulation technique developed as a therapy for various ophthalmological diseases. The application of TES is practical and easy to administer. Contact-lens-like electrodes are placed on the corneas of subjects and connected to a stimulator and stimulus isolator unit, while an inactive reference electrode is connected to the skin surrounding the eye [27]. This has been shown to have beneficial effects on the retina and optic nerve, leading to visual improvements in both preclinical [34-36,42,44,48,63-70] and clinical settings [71-76]. 


\subsection{Preclinical Studies}

Morimoto et al. were the first to report the use of TES in enhancing the survival of retinal ganglion cells (RGCs) after optic nerve transection in rats [34]. The neuroprotective effects of TES on RGCs were found to be associated with the upregulation of insulin growth factor 1 (IGF-1) by Müller glial cells in the retina [34,35]. The research team later demonstrated that the repeated administration of TES at optimal stimulation parameters (pulse width: 1 or $2 \mathrm{~ms} /$ phase; stimulation amplitude: 100 or $200 \mu \mathrm{A}$; stimulation frequency: 1, 5, or $20 \mathrm{~Hz}$; stimulation duration: $>30 \mathrm{~min}$ ) after optic nerve injury in rats provided the best neuroprotection and led to the regeneration of retinal axons [35,63]. Concordantly, the neuroprotective effects of TES on RGCs were also shown in rodent models of optic nerve crush [64-66], non-arteritic ischaemic optic neuropathy [67], ischaemic retinas [48], acute ocular hypertensive injury [42], and glaucoma [44]. The therapeutic applications of TES were not limited to preserving RGCs and their axons. In various transgenic models of retinal degeneration mimicking the pathological changes in human RP, TES treatment was reported to delay the degeneration of photoreceptors and ameliorate retinal functions [68-70]. These findings are in line with the findings of Ni et al., which demonstrated that TES could rescue photoreceptors and preserve electroretinogram (ERG) responses after excessive intense light exposure [36].

\subsection{Clinical Studies}

The therapeutic effects of TES in ophthalmology were further investigated in human subjects. In a study of 24 RP patients, six sessions of weekly TES, at a strength of $150 \%$ of the individual's electrical phosphene threshold (EPT), significantly increased the visual field area and ERG scotopic b-wave amplitude [71]. However, these results were not reproducible in a follow-up study on $52 \mathrm{RP}$ patients administered for 52 consecutive weeks with TES, possibly due to the natural progression of the disease [72]. Nevertheless, there was a significant improvement in the photopic ERG responses, suggesting a positive effect of TES on cone functions. In a similar study involving 13 patients with retinal artery occlusion, six sessions of TES at 150\% EPT improved photoreceptor activity as measured by an increased scotopic a-wave slope [73]. Two other small-scale clinical trials further reported that TES treatment had positive outcomes on retinal artery occlusion, with improvements observed in multifocal ERG, visual field, and visual acuity [74,75]. Another study provided further evidence of the therapeutic effects of TES, which showed acuity enhancements in two of three patients with non-arteritic ischaemic optic neuropathy and four of five patients with traumatic optic neuropathy [76].

\section{Mechanisms of Action of TES}

Although the therapeutic efficacy of TES in visual-related diseases was investigated in various preclinical and clinical studies, the precise mechanisms of its neuroprotective effects remain obscure. Several mechanisms were proposed to underlie the remedial effects of TES, including neurotrophic, neuroplastic, anti-inflammatory, anti-apoptotic, anti-glutamatergic, and vasodilation mechanisms (Figure 2). 


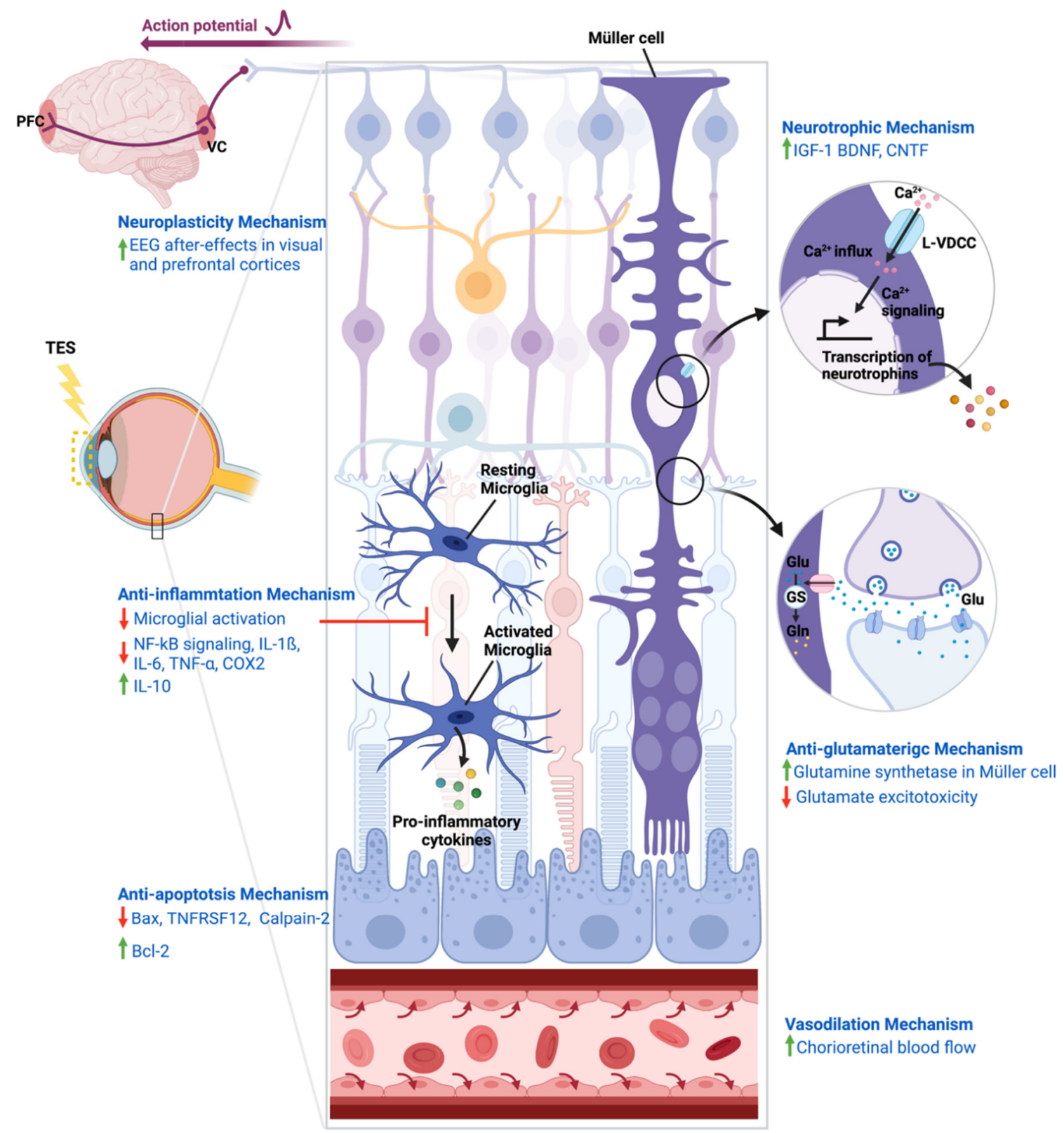

Figure 2. Potential mechanisms of the action of TES. The diagram shows the enlarged structures in retinal layers associated with several proposed mechanisms underlying the neuroprotective effects of TES. Overall, TES increases the survival of neurons and preserves their functions by promoting the expression of neurotrophins in Müller cells, reducing inflammation by inhibiting microglial activation, and preventing apoptotic cell death. TES administration was reported to enhance activities in the VC and PFC, possibly through repeated activation of the visual pathway leading to strengthened synaptic function and neuronal synchronization from the retina to the VC or to the PFC via cortical or subcortical routes. Additionally, TES was reported to rescue cells from glutamate-induced excitotoxicity by enhancing the release of glutamine synthetase from Müller cells. Increasing chorioretinal blood flow through vasodilation is proposed to underlie the protective effects of TES. Bax: Bcl-2-associated X protein; Bcl2: B-cell lymphoma 2; BDNF: brain-derived neurotrophic factor; CNTF: ciliary nerve trophic factor; COX2: cyclooxygenase-2; EEG: electroencephalogram; Glu: glutamate; Gln: glutamine; GS: glutamine synthetase; IGF-1: insulin-like growth factor 1; IL: interleukin; L-VDCC: L-type voltage-dependent calcium channel; NF-kB: nuclear factor $\mathrm{kB}$; PFC: prefrontal cortex; TES: transcorneal electrical stimulation; TNF- $\alpha$ : tumour necrosis factor- $\alpha$; Tnfrsf12a: TNF receptor superfamily member 12a; VC: visual cortex. Created with BioRender.com (accessed on 28 August 2021). 


\subsection{Neurotrophic Mechanism}

The neurotrophic mechanism is one of the prevailing theories that attributes the effects of TES to its ability to upregulate neurotrophin expression. Neurotrophins are a family of regulatory factors that are essential for the growth, survival, and functions of neurons [77]. In rodent models of optic nerve injury, TES effectively upregulated IGF-1 in Müller cells, and promoted RGC survival and axonal regeneration [34,35]. Interestingly, the regeneration of RGC axons was inhibited in the presence of an IGF-1 receptor antagonist, indicating the important role of the TES-induced production of IGF-1 in neuroprotection. Concordantly, TES positively modulated the expression of the brain-derived neurotrophic factor (BDNF) and ciliary neurotrophic factor (CNTF) in the retina, which prolonged the survival of photoreceptors and preserved retinal functions in mouse models of photoreceptor degeneration induced by light or N-methyl-N-nitrosourea [36,46]. Studies using Müller cell cultures also demonstrated that TES could stimulate the production of IGF-1, BDNF, and CNTF, resulting in significant induction of Müller cell proliferation [37-40]. The induction of these growth factors by electrical stimulation was suggested to be dependent on the activation of L-type voltage-dependent calcium channels (L-VDCCs), as blocking L-VDCCs downregulated IGF-1 and BDNF, as well as attenuating Müller cell proliferation [37,38,40].

\subsection{Neuroplasticity Mechanism}

The neuroplasticity mechanism of TES was demonstrated in electroencephalogram (EEG) studies. It was reported that TES in healthy rats led to EEG after-effects in the visual cortex, as demonstrated by a remarkable increase in theta power that lasted beyond the stimulation period by $15 \mathrm{~min}$ [33]. Likewise, TES in a mouse model of retinal degeneration increased the EEG power bands in both the visual and prefrontal cortices of awake animals [30]. In both EEG recording sites, the delta oscillations dominated over other frequency bands and were maintained for up to 3 weeks after stimulation. Given the association between slow delta waves and neuroplasticity, these results further reflected the neuroplastic after-effects of TES. Together, these studies suggested that TES could affect neurophysiological activity beyond the stimulation period, contributing to long-term depression or potentiation. The findings in rodent models paralleled the findings from a human study of optic nerve lesions that showed an increased EEG alpha spectrum in the occipital sites after electrical stimulation [78]. The author proposed that TES mediated visual functions through the induction of synaptic plasticity and neuronal synchronization in the occipital region. Moreover, TES was shown to activate the occipital visual cortex by stimulating RGCs, which generated action potentials that transmitted through the retinogeniculate pathway to the visual cortex [79]. When RGC activity was inhibited by tetrodotoxin, a sodium ion channel blocker, the generation of electrically evoked potentials was abolished in the visual cortex. This further supported the idea that TES conferred its effects through enforcing excitation potentials and synchronizing neuronal activity in the visual pathway. The repeated activation of the visual system could strengthen synaptic function, facilitating the transfer and processing of visual information, leading to visual improvements.

\subsection{Anti-Inflammatory Mechanism}

The anti-inflammatory mechanism suggested that the neuroprotective effects of TES can be explained through the blockade of microglial activation. In an in vitro model of light-induced photoreceptor degeneration, electrical stimulation was shown to suppress the activation of microglia, which in turn inhibited the secretion of pro-inflammatory interleukin (IL)-1 $\beta$ and the tumour necrosis factor (TNF)- $\alpha$, leading to decreased photoreceptor cell death [39]. These results were consistent with rodent experiments that showed that TES had immunomodulatory effects in suppressing retinal microglial activation after acute ocular hypertensive injury [42], optic nerve transection [43], and in a glaucoma model [44]. The improvement in RGC survival was accompanied by the upregulation of the anti-inflammatory cytokine IL-10 and the reduction of pro-inflammatory factors 
IL-6, TNF- $\alpha$, and cyclooxygenase-2 [42,43]. The activation of nuclear factor $\kappa \mathrm{B}$, a central mediator of inflammation, was also suppressed by TES in the retina [42]. Together, these findings provided evidence for the neuroprotective effect of TES on inflammation through inhibiting microglial activation and mediating the secretion of inflammatory cytokines.

\subsection{Anti-Apoptosis Mechanism}

Another candidate mechanism of the neuroprotective role of TES is through its antiapoptotic effects. It was reported that TES could activate the intrinsic survival system by increasing the gene and protein expression of anti-apoptotic B-cell lymphoma 2 (Bcl2) and by decreasing pro-apoptotic Bcl-2-associated $X$ protein (Bax) in the retina, which protected photoreceptors from light-induced degeneration [36]. In further support of the anti-apoptotic effects of TES, a microarray analysis revealed that TES induced the differential expression of 490 genes, including the downregulation of pro-apoptotic Bax and the TNF Receptor Superfamily Member 12A [45]. Additionally, calpain-2, a calciumsensitive protease that executes neuronal apoptosis, was also found to be downregulated after TES treatment, suggesting that the electrical stimulation could alleviate pro-apoptotic cellular calcium overload $[46,47]$. These findings showed that TES had a regulatory role in the apoptotic cascade, thereby preventing neurons from programmed cell death.

\subsection{Anti-Glutamatergic Mechanism}

The ability to alleviate glutamate-mediated excitotoxicity is another putative mechanism responsible for the therapeutic effects of TES. The excessive release of the excitatory neurotransmitter glutamate by damaged neurons could lead to further neuronal dysfunction and death as a result of calcium overload and oxidative stress, a process called glutamate excitotoxicity [80]. A study by Wang et al. reported that TES treatment in a rat model of retinal ischaemia resulted in the elevated expression of glutamine synthetase in Müller cells, subsequently protecting RGCs [48]. The induction of glutamine synthetase is an essential component of the glutamate clearance mechanism, in which glutamate is converted into non-toxic glutamine by glutamine synthetase after transportation to Müller cells [81]. The TES-induced upregulation of glutamine synthetase localized in the Müller cells suggested a neuroprotective mechanism by which TES regulated glutamate metabolism and prevented neuronal injury due to excitotoxicity.

\subsection{Vasodilation Mechanism}

An increased retinal blood flow could explain the therapeutic effects of TES in subjects with retinal ischaemic insult. A clinical study in healthy males demonstrated that a single 30 min session of TES increased the chorioretinal blood flow, which was sustained for $40 \mathrm{~h}$ after stimulation without significantly affecting the intraocular pressure and systemic blood circulation [49]. A randomised controlled trial on TES treatments in RP patients showed an improved blood flow in the optic nerve and retina [50]. Although the mechanism of how TES enhanced ocular circulation is unclear, researchers hypothesised that TES induced the release of molecules that mediated vasodilation. The vasodilation hypothesis is strengthened by the finding that TES upregulated IGF-1 expression [34,35], a growth factor that was shown to influence vasodilation through a nitrous oxide synthase-dependent pathway [82,83], which could lead to increased retinal blood flow. Furthermore, TES was reported to induce vasodilation and increase cerebral blood flow in a rat model of cerebral vasospasm through the stimulation of the ophthalmic division of trigeminal nerve endings in the cornea, suggesting the activation of the trigeminovascular reflex [84]. 


\section{Potential Antidepressant-like Activities of TES}

\subsection{Brain Regions Stimulated by TES}

The application of TES as a treatment for vision restoration was widely investigated. Interestingly, TES was shown to stimulate not only brain regions related to visual processing, but also other unrelated brain regions. A human study utilizing ${ }^{18} \mathrm{~F}$-fluorodeoxyglucose positron emission tomography examined brain regions stimulated during TES [29], which showed activation in the occipital cortex, including Brodmann's Area (BA) 17 in the primary visual cortex, and BA 18 and BA 19 in the secondary visual cortex. There was also activation in the inferior temporal gyrus, which is part of the ventral visual stream involved in visual processing. Aside from the visual cortex activation, enhanced brain activity was also recorded in the bilateral PFC and PHG. Rodent electrophysiological studies found that prolonged TES led to a sustained excitation of the PFC, suggesting that the stimulating effects of TES could diffuse beyond the visual pathway [30,31]. Although the functional implications of increased activity in PFC and PHG by TES remain obscure, they suggest that TES may exert effects on emotional regulation by activating brain regions highly associated with depression. Indeed, antidepressant treatments or psychotherapy were shown to normalize the PFC glucose hypometabolism observed in depressed patients [85,86], suggesting a positive association between PFC activity and the remission of depressive symptoms. A functional magnetic resonance imaging study demonstrated the involvement of the PFC in emotional control, as indicated by an increase in PFC activity during voluntary suppression of negative emotions $[87,88]$. Similarly, the PHG was shown to have a pathophysiological role in depression, as indicated by the high discriminative power of its functional connectivity in identifying depressed patients from healthy controls [89].

\subsection{TES-Induced Behavioural Changes in Corneally Kindled Models}

The effects of TES on behavioural alterations were previously demonstrated in corneally kindled rodent models [28,90,91]. Corneal kindling is an epileptic model generated through repeated TES at sub-convulsive doses until a generalized seizure is achieved. Wlaź et al. reported that TES induced a significant reduction in despair-like behaviour in fully kindled rats, as demonstrated by a decrease in force swim immobility [28]. Interestingly, such an antidepressant-like response was accompanied by an increase in anxiety-like behaviour in the elevated plus maze test. On the contrary, $6 \mathrm{~Hz}$ corneal kindling did not produce an anxiety-like response, instead it resulted in anhedonic-like behaviour in both saccharin preference and novelty suppressed feeding tests [90]. Furthermore, results reported by Wlaź et al. contradicted the findings of another study by Koshal et al., which showed corneally kindled mice had depressive-like behaviour in the tail suspension test [91]. Although TES was shown to induce behavioural changes in kindled models, its prodepressant or antidepressant effects remains unclear due to inconsistent results among studies. More importantly, these investigations were conducted in a fully kindled model, which is not a proper animal model of depression, and could display abnormal behavioural phenotypes that would confound the effects of TES on regulating mood-related behaviour. Moreover, the high stimulation intensities of TES (up to $19 \mathrm{~mA}$ amplitude) used to trigger epileptic seizures were inappropriate for examining the antidepressant potential of TES, as such extreme stimulation parameters could lead to tissue damage. Although TES was demonstrated to alter behaviour, its potential therapeutic use in depression needs to be investigated further in a proper animal model of depression using appropriate stimulation parameters.

\section{Comparison of FDA-Approved Treatments for Major Depression}

Interestingly, TES shares several mechanisms of action with some of the existing antidepressant treatments, which can provide a basis for identifying its putative antidepressant properties and the underlying molecular pathways. We compared selective serotonin reuptake inhibitors (SSRIs), repetitive transcranial magnetic stimulation (rTMS), and ECT (Table 1). These depression treatments are approved by the United States Food and Drug 
Administration (FDA) and are representative therapeutic options for major depression and TRD. Among the different SSRIs options, fluoxetine and escitalopram act to increase serotonin activity by maintaining its extracellular concentration. They are the most commonly prescribed first-line antidepressants with proven safety and efficacy for use in paediatric and adult patients [92,93]. As a non-surgical, non-convulsive brain stimulation therapy, rTMS utilizes a time-varying magnetic field to modulate cortical plasticity and excitability $[94,95]$. Another non-invasive neuromodulation technique is ECT, which is conducted under general anaesthesia. It intentionally triggers a brief generalized cerebral seizure via the delivery of a small electrical charge to the patient's scalp [96]. It is speculated that the neurotrophic, anti-apoptotic, and anti-inflammatory activities of TES greatly resemble the biomarker changes observed in the aforementioned antidepressant pharmacological and neuromodulation interventions.

Table 1. The shared mechanisms of action of TES for visual improvement and FDA-approved treatments for depression. The associated biomarkers and/or behavioural changes of TES-induced neurotrophic, anti-apoptotic, and anti-inflammatory mechanisms in preclinical ophthalmology studies are compared with those of FDA-approved treatments for depression, namely, the SSRIs, rTMS, and ECT.

\begin{tabular}{|c|c|c|c|c|}
\hline Treatment & Study & Subject & Administration Protocol & Results \\
\hline \multicolumn{5}{|c|}{ Neurotrophic Mechanism } \\
\hline \multirow{8}{*}{ 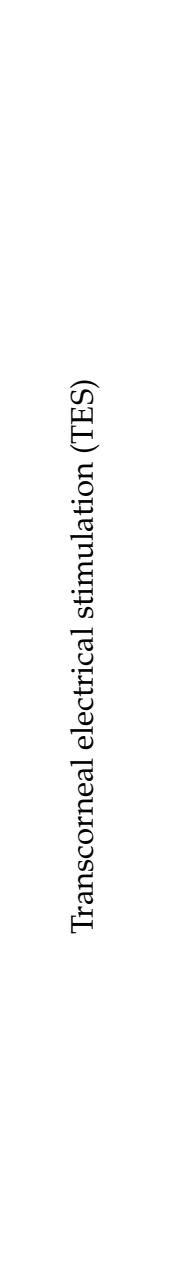 } & {$[34]$} & $\begin{array}{l}\text { Male Wistar rats, model of } \\
\text { optic nerve transection }\end{array}$ & $\begin{array}{c}100 \mu \mathrm{A}, 20 \mathrm{~Hz}, 3 \mathrm{~ms} / \text { phase, } \\
1 \mathrm{~h}, 1 \text { session }\end{array}$ & $\begin{array}{l}\text { TES increased survival of axotomized } \\
\text { RGCs and expression of IGF-1 in } \\
\text { Müller cells in the retina. }\end{array}$ \\
\hline & [37] & Retinal Müller cell culture & $\begin{array}{c}1-10 \mathrm{~mA}, 20 \mathrm{~Hz}, 1 \mathrm{~ms} / \text { phase, } \\
30 \mathrm{~min}, 1 \text { session }\end{array}$ & $\begin{array}{l}\text { Stimulation increased IGF-1 mRNA } \\
\text { and } \mathrm{Ca}^{2+} \text { reflux which were } \\
\text { suppressed by an L-VDCC blocker. }\end{array}$ \\
\hline & [38] & Retinal Müller cell culture & $\begin{array}{l}10 \mathrm{~mA}, 20 \mathrm{~Hz}, 1 \mathrm{~ms} / \text { phase, } \\
30 \mathrm{~min}, 1 \text { session }\end{array}$ & $\begin{array}{l}\text { Stimulation increased BDNF mRNA } \\
\text { and intracellular protein levels which } \\
\text { were suppressed by L-VDCC blocker. }\end{array}$ \\
\hline & [36] & $\begin{array}{l}\text { Male Sprague Dawley rats, } \\
\text { model of light-induced } \\
\text { photoreceptor } \\
\text { degeneration }\end{array}$ & $\begin{array}{c}\text { Pre-TES: } 100-500 \mu \mathrm{A}, \\
20-100 \mathrm{~Hz}, 3 \mathrm{~ms} / \text { phase, } 1.5 \mathrm{~h} \text {, } \\
1 \text { session. } \\
\text { Post-TES: } 200 / 300 \mu \mathrm{A}, 20 \mathrm{~Hz}, \\
3 \mathrm{~ms} / \text { phase, } 1 \text { session every } \\
3 \text { days for up to } 14 \text { days }\end{array}$ & $\begin{array}{c}\text { Post-TES better preserved ONL and } \\
\text { retinal functions. TES increased gene } \\
\text { and protein expressions of CNTF and } \\
\text { BDNF. }\end{array}$ \\
\hline & [35] & $\begin{array}{l}\text { Male Wistar rats; model of } \\
\text { optic nerve crush }\end{array}$ & $\begin{array}{c}100 \mu \mathrm{A}, 20 \mathrm{~Hz}, 1 \mathrm{~ms} / \mathrm{phase} \\
1 \mathrm{~h}, 1 \text { session on day } 0 ; \\
2 \text { sessions on day } 0 \text { and } 7 ; 4 \\
\text { sessions on day } 0,4,7 \text {, and } 10 ; \\
\text { daily sessions on day } 0-12\end{array}$ & $\begin{array}{l}\text { TES increased IGF-1 immunoreactivity } \\
\text { in the retina, and promoted axonal } \\
\text { regeneration and survival of RGCs. } \\
\text { The axonal regeneration was inhibited } \\
\text { with an IGF-1 receptor antagonist. }\end{array}$ \\
\hline & [39] & $\begin{array}{l}\text { Retinal microglia and } \\
\text { Müller cell culture with } \\
\text { intense light exposure }\end{array}$ & $\begin{array}{c}300 / 500 / 1000 / 1600 \mu \mathrm{A}, 20 \mathrm{~Hz} \\
3 \mathrm{~ms} / \text { phase, } 1 \mathrm{~h}, 1 \text { session }\end{array}$ & $\begin{array}{l}\text { Stimulation increased secretion of } \\
\text { BDNF and CNTF by Müller cells. }\end{array}$ \\
\hline & [46] & $\begin{array}{l}\text { C57/BL mice, MNU model } \\
\text { of photoreceptor } \\
\text { degeneration }\end{array}$ & $\begin{array}{c}100 / 200 \mu \mathrm{A}, 20 \mathrm{~Hz} \\
3 \mathrm{~ms} / \text { phase, } 3 \text { sessions on days } \\
1,3 \text {, and } 6 \text { after MNU injection }\end{array}$ & $\begin{array}{l}\text { TES ameliorated photoreceptor } \\
\text { degeneration and increased mRNA } \\
\text { levels of BDNF and CNTF. }\end{array}$ \\
\hline & [40] & Retinal Müller cell culture & $\begin{array}{l}10-500 \mu \mathrm{A}, 10-100 \mathrm{~Hz} \\
0.5-5 \mathrm{~ms} / \text { phase }\end{array}$ & $\begin{array}{l}\text { TES induced Müller cell proliferation } \\
\text { which was blocked by an L-type } \\
\text { calcium channel blocker. TES also } \\
\text { increased CNTF mRNA level. }\end{array}$ \\
\hline
\end{tabular}


Table 1. Cont.

\begin{tabular}{|c|c|c|c|c|}
\hline Treatment & Study & Subject & Administration Protocol & Results \\
\hline \multicolumn{5}{|c|}{ Neurotrophic Mechanism } \\
\hline \multirow{2}{*}{ 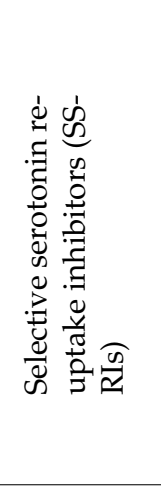 } & [97] & $\begin{array}{l}21 \text { patients with depression } \\
23 \text { healthy controls }\end{array}$ & Escitalopram, 12 weeks & $\begin{array}{l}\text { Escitalopram in depressed patients } \\
\text { increased leukocyte BDNF mRNA and } \\
\text { serum BDNF to similar levels as in } \\
\text { controls. Changes in BDNF levels } \\
\text { were correlated with symptoms } \\
\text { improvement. }\end{array}$ \\
\hline & [98] & $\begin{array}{l}5 \text { patients with depression } \\
10 \text { healthy controls }\end{array}$ & $\begin{array}{c}\text { Escitalopram, } 10 \mathrm{mg} / \text { day, } \\
8 \text { weeks }\end{array}$ & $\begin{array}{l}\text { Escitalopram in depressed patients } \\
\text { improved GDS scores and increased } \\
\text { serum BDNF beyond the levels in } \\
\text { controls. The increase in BDNF was } \\
\text { correlated to the improved GDS } \\
\text { scores. }\end{array}$ \\
\hline \multirow{5}{*}{ 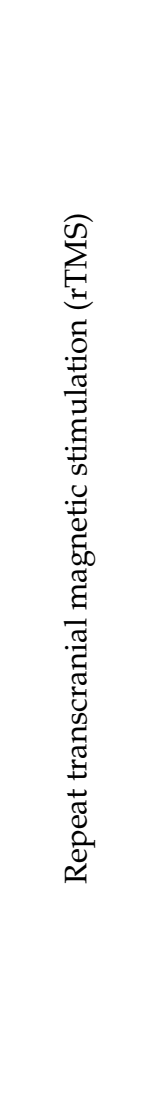 } & [99] & $\begin{array}{l}16 \text { patients with } \\
\text { treatment-resistant } \\
\text { depression }\end{array}$ & $\begin{array}{l}1 \mathrm{~Hz} / 17 \mathrm{~Hz}, 5 \text { consecutive } \\
\text { sessions with } 24 \mathrm{~h} \text { interval }\end{array}$ & $\begin{array}{l}\text { rTMS improved HDRS scores and } \\
\text { increased serum BDNF. }\end{array}$ \\
\hline & [100] & $\begin{array}{l}26 \text { patients with } \\
\text { treatment-resistant } \\
\text { depression }\end{array}$ & $\begin{array}{l}\text { Stimulated in the left PFC, } \\
\text { intensity } 80 \% \mathrm{MT}, 20 \mathrm{~Hz}, \\
800 \text { pulses/day, } 10 \text { days }\end{array}$ & $\begin{array}{l}\text { rTMS improved HDRS scores and } \\
\text { increased plasma BDNF by } 23 \% \text { in } \\
\text { responders. A trend of an association } \\
\text { between changes in HDRS scores and } \\
\text { BDNF levels was found with rTMS. }\end{array}$ \\
\hline & [101] & $\begin{array}{l}\text { Male Sprague Dawley rats; } \\
\text { CUMS model of depression }\end{array}$ & $\begin{array}{l}15 \mathrm{~Hz} \text {, intensity } 100 \% \text { of } \\
\text { device's maximum power, } \\
60 \text { pulses / train, } 15 \mathrm{~s} \text { train } \\
\text { duration, } 15 \mathrm{~s} \text { intertrain } \\
\text { interval, } 17 \text { trains / day, } \\
1000 \text { pulses / day, } \\
21 \text { consecutive days }\end{array}$ & $\begin{array}{l}\text { rTMS improved depressive-like } \\
\text { behaviour and increased BDNF } \\
\text { protein levels in the hippocampus. }\end{array}$ \\
\hline & [102] & $\begin{array}{l}\text { Male Sprague Dawley rats; } \\
\text { CUMS model of depression }\end{array}$ & $\begin{array}{c}15 \mathrm{~Hz} \text {, intensity } 100 \% \text { of } \\
\text { device's maximum power, } \\
15 \text { trains of } 60 \text { pulses with } 15 \mathrm{~s} \\
\text { inter-train interval, } \\
900 \text { pulses / day, } 7 \text { days }\end{array}$ & $\begin{array}{l}\text { rTMS improved depressive-like } \\
\text { behaviour and increased BDNF } \\
\text { protein levels in the hippocampus. }\end{array}$ \\
\hline & [103] & $\begin{array}{c}58 \text { patients with } \\
\text { treatment-resistant } \\
\text { depression: } \\
\text { rTMS }(n=19) ; \text { non-rTMS } \\
\text { controls }(n=19) \\
30 \text { healthy individuals: } \\
\text { rTMS }\end{array}$ & $\begin{array}{l}\text { Stimulated in left dlPFC, } \\
\text { intensity } 80 \% \mathrm{MT}, 10 \mathrm{~Hz}, \\
1200 \text { pulses of } 1 \mathrm{~s} \text { with } 11 \mathrm{~s} \\
\text { interval, } 20 \mathrm{~min} / \text { session, } \\
5 \text { sessions/week, } 4 \text { weeks. }\end{array}$ & $\begin{array}{l}\text { rTMS in depressed patients improved } \\
\text { HDRS scores and increased serum } \\
\text { BDNF, which was negatively } \\
\text { correlated with HDRS scores. }\end{array}$ \\
\hline \multirow{2}{*}{ 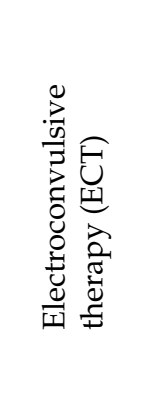 } & [104] & Male Sprague Dawley rats & $\begin{array}{l}\text { Stimulated with ear clip } \\
\text { electrodes, } 100 \mathrm{~V}, 50 \mathrm{~Hz}, 1.5 \mathrm{~s}, \\
\text { duration, } 1 \text { session/day, } \\
10 \text { days }\end{array}$ & $\begin{array}{l}\text { ECT increased BDNF protein level in } \\
\text { the hippocampus. ECT also decreased } \\
\text { BDNF protein level in the VTA, which } \\
\text { was necessary for the } \\
\text { antidepressant-like effects of ECT. }\end{array}$ \\
\hline & [105] & $\begin{array}{l}\text { Meta-analysis of } 11 \text { studies } \\
\text { enrolled patients with } \\
\text { unipolar, bipolar and } \\
\text { psychotic depression }\end{array}$ & $\begin{array}{l}\text { Stimulated unilaterally or } \\
\text { bilaterally on } \\
\text { frontal/temporal/frontotemporal } \\
\text { positions, } 2-3 \text { sessions/week, } \\
\text { 6-12 sessions }\end{array}$ & ECT increased blood BDNF levels. \\
\hline
\end{tabular}


Table 1. Cont.

\begin{tabular}{|c|c|c|c|c|}
\hline Treatment & Study & Subject & Administration Protocol & Results \\
\hline \multicolumn{5}{|c|}{ Neurotrophic Mechanism } \\
\hline & [106] & 24 patients with depression & $\begin{array}{l}\text { Stimulated unilaterally in right } \\
\text { frontotemporal and parietal } \\
\text { position, maximum charge } \\
1000 \mathrm{mC}, 3 \text { sessions / week, } \\
\text { 6-13 sessions }\end{array}$ & $\begin{array}{l}\text { ECT improved HDRS scores in } \\
\text { responders and remitters, and } \\
\text { increased serum BDNF up to } 1 \text { month } \\
\text { after the last treatment. }\end{array}$ \\
\hline
\end{tabular}

\begin{tabular}{|c|c|c|c|c|}
\hline \multicolumn{5}{|c|}{ Anti-apoptosis Mechanism } \\
\hline \multirow{3}{*}{ 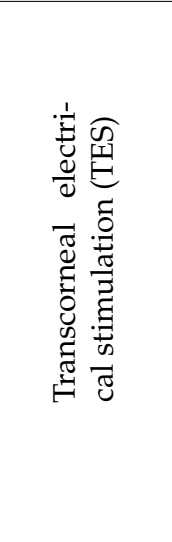 } & {$[36]$} & $\begin{array}{c}\text { Male Sprague Dawley rats } \\
\text { with light-induced } \\
\text { photoreceptor } \\
\text { degeneration }\end{array}$ & $\begin{array}{c}\text { Pre-TES: } 100-500 \mu \mathrm{A}, \\
20-100 \mathrm{~Hz}, 3 \mathrm{~ms} / \text { phase, } 1.5 \mathrm{~h} \text {, } \\
1 \text { session. } \\
\text { Post-TES: } 200 / 300 \mu \mathrm{A}, 20 \mathrm{~Hz}, \\
3 \mathrm{~ms} / \text { phase, } 1 \text { session every } \\
3 \text { days for up to } 14 \text { days }\end{array}$ & $\begin{array}{l}\text { Post-TES better preserved ONL and } \\
\text { retinal functions. TES increased gene } \\
\text { and protein expression of Bcl- } 2 \text { and } \\
\text { decreased expression of Bax. }\end{array}$ \\
\hline & {$[45]$} & Male brown Norway rats & $\begin{array}{c}200 \mu \mathrm{A}, 20 \mathrm{~Hz}, 1 \mathrm{~ms} / \text { phase } \\
1 \mathrm{~h} \text {, one session }\end{array}$ & $\begin{array}{c}\text { TES differentially regulated } 490 \text { genes, } \\
\text { including downregulation of Bax and } \\
\text { Tnfrs12a. }\end{array}$ \\
\hline & [46] & $\begin{array}{l}\text { C57/BL mice; MNU model } \\
\text { of photoreceptor } \\
\text { degeneration }\end{array}$ & $\begin{array}{c}100 / 200 \mu \mathrm{A}, 20 \mathrm{~Hz} \\
3 \mathrm{~ms} / \text { phase, } 3 \text { sessions on days } \\
1,3 \text {, and } 6 \text { after MNU injection }\end{array}$ & $\begin{array}{c}\text { TES ameliorated photoreceptor } \\
\text { degeneration, increased mRNA Bcl-2 } \\
\text { mRNA, and decreased Bax and } \\
\text { Calpain-2 mRNA levels. }\end{array}$ \\
\hline \multirow{2}{*}{ 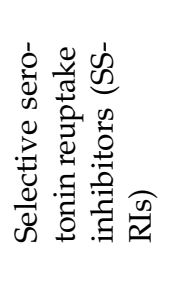 } & [107] & $\begin{array}{l}\text { Male Sprague Dawley rats; } \\
\text { CUMS model of depression }\end{array}$ & $\begin{array}{l}\text { Fluoxetine, } 5 \mathrm{mg} / \mathrm{kg} / \text { day, i.p., } \\
21 \text { days }\end{array}$ & $\begin{array}{l}\text { Fluoxetine decreased Bax mRNA in } \\
\text { the hippocampus and increased Bcl-2 } \\
\text { mRNA in } \mathrm{CeA}, \mathrm{Cg} \text {, and Fr. }\end{array}$ \\
\hline & [108] & $\begin{array}{l}\text { Male Sprague Dawley rats; } \\
\text { CUMS model of depression }\end{array}$ & Fluoxetine, 3 weeks & $\begin{array}{l}\text { Fluoxetine improved depressive-like } \\
\text { behaviour, increased Bcl-2 and } \\
\text { decreased caspase-3 protein levels in } \\
\text { the hippocampus. }\end{array}$ \\
\hline \multirow{2}{*}{ 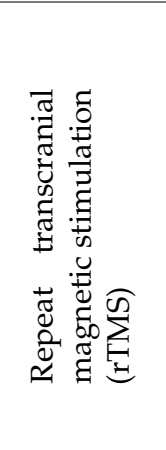 } & [102] & $\begin{array}{l}\text { Male Sprague Dawley rats; } \\
\text { CUMS model of depression }\end{array}$ & $\begin{array}{c}15 \mathrm{~Hz} \text {, intensity } 100 \% \text { of } \\
\text { device's maximum power, } \\
15 \text { trains of } 60 \text { pulses with } 15 \mathrm{~s} \\
\text { inter-train interval, } \\
900 \text { pulses / day, } 7 \text { days }\end{array}$ & $\begin{array}{c}\text { rTMS improved depressive-like } \\
\text { behaviour, increased Bcl-2, and } \\
\text { decreased Bax protein levels in the } \\
\text { hippocampus. }\end{array}$ \\
\hline & [109] & $\begin{array}{l}\text { Male Sprague Dawley rats; } \\
\text { CUMS model of depression }\end{array}$ & $\begin{array}{c}10 \mathrm{~Hz} \text {, intensity } 50 \% \text { of MT, } 1 \mathrm{~s} \\
\text { stimulation duration, } 10 \mathrm{~s} \\
\text { inter-pulse interval, } 500 \\
\text { pulses / day, } 10 \text { min } / \text { day, } \\
5 \text { daily sessions with 2-day } \\
\text { intervals for } 3 \text { weeks }\end{array}$ & $\begin{array}{l}\text { rTMS improved depressive-like } \\
\text { behaviour, decreased Bax mRNA and } \\
\text { protein levels in the hippocampus. }\end{array}$ \\
\hline \multirow[t]{2}{*}{ 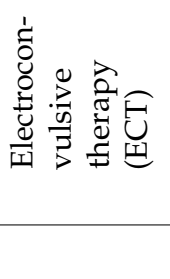 } & [107] & $\begin{array}{l}\text { Male Sprague Dawley rats; } \\
\text { CUMS model of depression }\end{array}$ & $\begin{array}{l}\text { Stimulated with ear clip } \\
\text { electrodes, } 60 \mathrm{~mA}, 0.3 \mathrm{~s} \\
\text { duration, } 1 \text { session daily for } \\
21 \text { days }\end{array}$ & $\begin{array}{l}\text { ECT increased } \mathrm{Bcl}-2 \text { mRNA in } \mathrm{Cg} \text {, } \\
\text { lateral } \mathrm{Fr}, \mathrm{CeA} \text {, and Bcl-xl mRNA in } \\
\text { the hippocampus. }\end{array}$ \\
\hline & \multicolumn{4}{|c|}{ Anti-inflammation Mechanism } \\
\hline \multirow{2}{*}{ 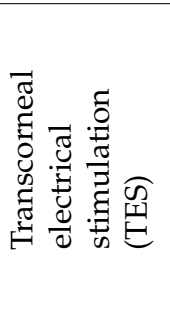 } & [39] & $\begin{array}{l}\text { Retinal microglia and } \\
\text { Müller cells culture with } \\
\text { intense light exposure }\end{array}$ & $\begin{array}{c}300 / 500 / 1000 / 1600 \mu \mathrm{A}, 20 \mathrm{~Hz} \\
3 \mathrm{~ms} / \text { phase, } 1 \mathrm{~h}, 1 \text { session }\end{array}$ & $\begin{array}{c}\text { Stimulation inhibited microglial } \\
\text { activation and microglial secretion of } \\
\text { IL-1 } \beta \text { and TNF- } \alpha \text {. }\end{array}$ \\
\hline & [43] & $\begin{array}{l}\text { Male Sprague Dawley rats; } \\
\text { model of optic nerve } \\
\text { transection }\end{array}$ & $\begin{array}{c}200 \mu \mathrm{A}, 20 \mathrm{~Hz}, 2 \mathrm{~ms} / \mathrm{phase}, \\
1 \mathrm{~h}, 2 \text { sessions on day } 0 \text { and } \\
\text { day } 4 \text {; or } 4 \text { sessions on day } 0,4 \text {, } \\
7 \text { and } 10 \text { after optic nerve } \\
\text { transection }\end{array}$ & $\begin{array}{l}\text { TES increased survival of RGCs, } \\
\text { suppressed microglial activation, and } \\
\text { reduced TNF- } \alpha \text { expression in } \\
\text { microglia. }\end{array}$ \\
\hline
\end{tabular}


Table 1. Cont.

\begin{tabular}{|c|c|c|c|c|}
\hline Treatment & Study & Subject & Administration Protocol & Results \\
\hline \multicolumn{5}{|c|}{ Neurotrophic Mechanism } \\
\hline & [42] & $\begin{array}{l}\text { Mongolian gerbils; model } \\
\text { of acute ocular } \\
\text { hypertensive injury }\end{array}$ & $\begin{array}{c}100 \mu \mathrm{A}, 20 \mathrm{~Hz}, 1 \mathrm{~ms} / \mathrm{phase}, 1 \mathrm{~h}, \\
2 \text { sessions on day } 1 \text { and } 4 \text { for } \\
\text { the } 1 \text {-week experiment; or } \\
2 \text { sessions on day } 1 \text { and } 4 \text { each } \\
\text { week for the } 1 \text {-month } \\
\text { experiment }\end{array}$ & $\begin{array}{l}\text { TES improved retinal function and } \\
\text { survival of RGCs, decreased pNF- } \mathrm{B} \text {, } \\
\text { IL-6, Cox } 2 \text { and TNF- } \alpha \text { expressions, } \\
\text { increased IL-10 levels, and suppressed } \\
\text { microglial activation. }\end{array}$ \\
\hline & {$[44]$} & $\begin{array}{l}\text { DBA/2 J mice, model of } \\
\text { glaucoma }\end{array}$ & $\begin{array}{c}100 \mu \mathrm{A}, 20 \mathrm{~Hz}, 1 \mathrm{~ms} / \text { phase, } \\
10 \mathrm{~min} \text {, every } 3 \text { days for } \\
8 \text { weeks }\end{array}$ & $\begin{array}{l}\text { TES improved RGC axonal survival } \\
\text { and reduced the number of microglia. }\end{array}$ \\
\hline \multirow{2}{*}{ 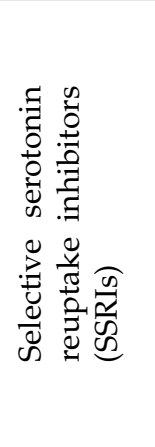 } & [110] & 98 patients with depression & $\begin{array}{c}\text { Fluoxetine, } 20 \mathrm{mg} / \text { day, } \\
8 \text { weeks } \\
\text { Or escitalopram, } 20 \mathrm{mg} / \text { day, } \\
8 \text { weeks }\end{array}$ & $\begin{array}{l}\text { Fluoxetine and escitalopram reduced } \\
\text { inflammatory markers, including } \\
\text { C-reactive protein concentration, } \\
\text { erythrocyte sedimentation rate, and } \\
\text { white blood cell count. }\end{array}$ \\
\hline & [111] & $\begin{array}{l}\text { Meta-analysis of } 22 \text { studies } \\
\text { on enrolled patients with } \\
\text { depression who were } \\
\text { taking FDA-approved } \\
\text { pharmacological } \\
\text { treatments }\end{array}$ & $\begin{array}{c}\text { Different classes of } \\
\text { antidepressants were included, } \\
\text { primarily SSRIs }\end{array}$ & $\begin{array}{l}\text { SSRIs in depressed patients reduced } \\
\text { serum IL-6, IL-1ß, and TNF- } \alpha \text {. }\end{array}$ \\
\hline \multirow{2}{*}{ 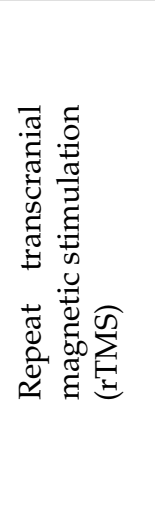 } & [112] & $\begin{array}{l}\text { Male Sprague Dawley rats; } \\
\text { CUMS model of depression }\end{array}$ & $\begin{array}{c}15 \mathrm{~Hz} \text {, intensity } 30 \% \text { of } \\
\text { device's maximum power, } 20 \mathrm{~s} \\
\text { train duration, } 15 \mathrm{~min} \\
\text { intertrain interval, } 900 \\
\text { pulses/day, seven consecutive } \\
\text { days }\end{array}$ & $\begin{array}{l}\text { rTMS improved depressive-like } \\
\text { behaviour, increased Nrf2 proteins } \\
\text { and decreased TNF-a, iNOS, IL-1ß, } \\
\text { and IL- } 6 \text { expression in the } \\
\text { hippocampus. These effects were } \\
\text { reversed by Nrf2 silencing. }\end{array}$ \\
\hline & [103] & $\begin{array}{c}58 \text { patients with } \\
\text { treatment-resistant } \\
\text { depression: } \\
\text { rTMS }(n=19) ; \text { non-rTMS } \\
\text { controls }(n=19) \\
30 \text { healthy individuals: } \\
\text { rTMS }\end{array}$ & $\begin{array}{l}\text { Stimulated in left dlPFC, } \\
\text { intensity } 80 \% \text { MT, } 10 \mathrm{~Hz} \text {, } \\
1200 \text { pulses of } 1 \mathrm{~s} \text { with } 11 \mathrm{~s} \\
\text { interval, } 20 \text { min/session, } 5 \\
\text { sessions/week, } 4 \text { weeks }\end{array}$ & $\begin{array}{l}\text { rTMS in depressed patients improved } \\
\text { HDRS scores and decreased serum } \\
\text { IL-1ß and TNF-a to levels similar to } \\
\text { healthy individuals. IL-1ß and TNF-a } \\
\text { levels were positively correlated with } \\
\text { HAMD scores. }\end{array}$ \\
\hline \multirow{3}{*}{ 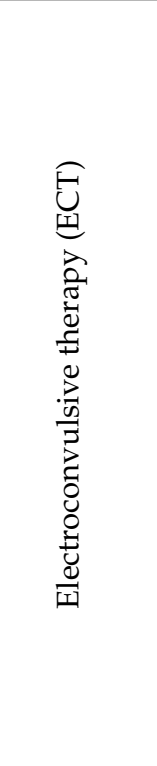 } & [113] & $\begin{array}{l}23 \text { patients with } \\
\text { depression: ECT }(n=15) ; \\
\text { non-ECT control }(n=8) \\
15 \text { healthy controls }\end{array}$ & $\begin{array}{c}\text { Maximum charge } 504 \mathrm{mC} \text {, } \\
\text { intensity } 0.9 \mathrm{~A} \text {, max duration } \\
7.9 \mathrm{~s}, 3 \text { sessions/week, } \\
4-18 \text { sessions }\end{array}$ & $\begin{array}{l}\text { ECT in depressed patients decreased } \\
\text { plasma levels of TNF- } \alpha \text { to levels } \\
\text { comparable with healthy controls. }\end{array}$ \\
\hline & [114] & 15 patients with depression & $\begin{array}{l}\text { Stimulated unilaterally on the } \\
\text { right d'Elia position, intensity } \\
0.9 \mathrm{~A}, 10-70 \mathrm{~Hz} \\
0.5-1.0 \mathrm{~ms} / \text { phase, } 6-8 \mathrm{~s} \\
\text { stimulus duration, max charge } \\
964 \mathrm{mC}, 2-3 \text { sessions / week, } \\
12 \text { sessions }\end{array}$ & $\begin{array}{c}\text { ECT decreased serum levels of } \\
\text { eotaxin-3 and IL-5 } 24 \mathrm{~h} \text { after the last } \\
\text { ECT. }\end{array}$ \\
\hline & [115] & $\begin{array}{l}50 \text { patients with } \\
\text { treatment-resistant } \\
\text { depression }\end{array}$ & $\begin{array}{l}\text { Stimulated bilaterally in } \\
\text { temporal position, square } \\
\text { wave pulse, intensity } \\
550-800 \mathrm{~mA}, 40-90 \mathrm{~Hz}, \\
1-2 \mathrm{~ms} / \text { pulse, } 0.5-4 \mathrm{~s} \\
\text { stimulation duration, } \\
\text { maximum charge } 1172 \mathrm{mC}, 3 \\
\text { sessions / week, } 5-12 \text { sessions }\end{array}$ & $\begin{array}{c}\text { ECT increased serum levels of IL-1 } \\
\text { and IL-10, and decreased levels of IL-4 } \\
\text { and IFN- } \gamma \text {. }\end{array}$ \\
\hline
\end{tabular}


Table 1. Cont.

\begin{tabular}{|c|c|c|c|c|}
\hline Treatment & Study & Subject & Administration Protocol & Results \\
\hline \multicolumn{5}{|c|}{ Neurotrophic Mechanism } \\
\hline & [116] & 30 patients with depression & $\begin{array}{c}\text { Intensity at } 1.5 \text { times of seizure } \\
\text { threshold, } 3 \text { sessions / week, } \\
5-17 \text { sessions }\end{array}$ & $\begin{array}{l}\text { ECT decreased plasma TNF- } \alpha \text { level } 2 \\
\text { and } 4 \mathrm{~h} \text { after treatment in the 1st, } 5 \text { th, } \\
\text { and last ECT sessions. }\end{array}$ \\
\hline & [117] & 62 patients with depression & $\begin{array}{l}\text { Stimulated unilaterally on the } \\
\text { right, } 2 \text { sessions/week until } \\
\text { patients were } \\
\text { asymptomatic/did not } \\
\text { improve further for } 3 \\
\text { sessions/intolerable side } \\
\text { effects occurred }\end{array}$ & $\begin{array}{c}\text { ECT decreased plasma IL-6 level. } \\
\text { TNF } \alpha \text { level remained unchanged after } \\
\text { ECT. }\end{array}$ \\
\hline
\end{tabular}

Bax: Bcl-2-associated X protein; Bcl-2: B-cell lymphoma 2; Bcl-xl: B-cell lymphoma-extra large; BDNF: brain-derived neurotrophic factor; $\mathrm{CeA}$ : central nucleus of the amygdala; $\mathrm{Cg}$ : cingulate cortex; CNTF: ciliary neurotropic factor; Cox-2: cyclooxygenase-2; CUMS: chronic unpredictable mild stress; dlPFC: dorsolateral prefrontal cortex; ERG: electroretinogram; Fr: frontal cortex; GDS: Geriatric Depression Scale; HAMD: Hamilton Depression Rating Scale; IGF-1: insulin-like growth factor 1; IL: interleukin; iNOS: inducible nitric oxide synthase; L-VDCC: L-type voltage-dependent calcium channel; MNU: N-methyl-N-nitrosourea; MT: motion threshold; Nrf2: nuclear factor-E2-related factor 2; ONL: outer nuclear layer; pNF-kB: phosphorylated nuclear factor $\mathrm{kB}$; RGCs: retinal ganglion cells; RP: retinitis pigmentosa; TNF- $\alpha$ : tumour necrosis factor $\alpha$; Tnfrs: tumour necrosis factor receptor superfamily; VTA: ventral tegmental area.

A growing body of evidence suggests the regulation of neurotrophic signalling has tremendous potential for treating depression. Impaired neuroplasticity is thought to arise from the dysregulated expression of neurotrophins, which have dual roles in regulating neuronal survival and activity-dependent synaptic plasticity $[118,119]$. Specifically, it has long been speculated that BDNF, a major neurotrophic factor that supports the growth, maturation, and maintenance of nerve cells, plays a direct role in the pathophysiology of depression [120]. A decreased plasma BDNF level was found to be significantly associated with suicidal behaviour in major depression [121]. Similar to TES, the administration of rTMS, ECT, and SSRIs in depressed subjects also led to a neurotrophic enhancement, particularly the enhanced expression of BDNF. Indeed, a 12-week escitalopram treatment in depressed patients reversed the downregulated BDNF mRNA levels in peripheral leukocytes, which normalised serum BDNF levels and alleviated depressive symptoms [97]. Similarly, a small cohort of depressed older patients was treated with escitalopram for 2 months, which resulted in a significant increase in BDNF serum level associated with improvements in the geriatric depression score [98]. Likewise, prolonged rTMS administration in a chronic unpredictable mild stress (CUMS) model of depression upregulated hippocampal BDNF expression for up to 2 weeks after treatment discontinuation and reversed the stress-induced depressive-like behavioural changes [101,102]. Concordantly, several lines of evidence demonstrated that TRD patients who received rTMS showed remarkable increases in peripheral BDNF levels $[99,100,103]$. Similarly, ECT was shown to upregulate BDNF expression in depressed subjects in both preclinical and clinical studies [104-106]. A recent meta-analysis showed that ECT increased peripheral BDNF levels in depressed patients consistent with pharmacological antidepressant interventions, and further highlighted the association between BDNF and the risk of depression [105]. Although the effects of TES on enhancing BDNF levels in the retina are consistently reported $[36,38,39,46]$, its effects on regulating neurotrophin expression in various brain regions involved in emotional regulation, and its associated therapeutic potential, require further investigation.

In major depression, chronic stress can induce excessive apoptotic cell death leading to neurodegeneration in the central nervous system [122]. A balance between pro-apoptotic factors (e.g., Bax and Bak) and anti-apoptotic factors (e.g., Bcl-2 and Bcl-xl) plays a crucial role in controlling the activation of apoptotic pathways [123]. Studies showed that TES could upregulate anti-apoptotic Bcl-2 expression and downregulate pro-apoptotic Bax expression $[36,45,46]$. Similarly, SSRIs were shown to protect neurons from apoptosis by 
modulating the expression of the Bcl-2 gene family members that regulate caspase activation and cell death [124]. Fluoxetine treatment in a CUMS model enhanced Bcl-2 expression in the central nucleus of the amygdala, frontal, and cingulate cortices, and reduced Bax expression in the hippocampus, which are all critical brain regions implicated in depression $[107,125]$. Concordantly, changes in apoptotic markers such as the downregulation of Bcl-2 and upregulation of caspase- 3 were remarkably attenuated in CUMS rats after 3 weeks of fluoxetine treatment, further supporting an anti-apoptotic mechanism of SSRIs [108]. Similarly, ECT was found to positively affect Bcl-2 mRNA expression in various sub-regions of the limbic system, while also selectively increasing Bcl-xl mRNA expression in the hippocampus [107]. On the other hand, rTMS was able to repress Bax and augment Bcl-2 expression levels in the hippocampus of CUMS rats, which were accompanied by the amelioration of depression-like behaviour [102,109]. Although TES was also shown to possess anti-apoptotic properties, whether these resulted in antidepressant activity remains an interesting topic for future investigation.

The inflammatory hypothesis of depression is supported by the heightened inflammatory responses found in a significant proportion of the depressed population [126], including increased levels of neuroinflammatory cytokines, which are believed to cause serotonin and melatonin depletion via the neurotoxic kynurenine pathway [127]. Interestingly, changes in the pro- and anti-inflammatory profile of TES greatly paralleled that of rTMS, ECT, and SSRIs. A meta-analysis reported SSRIs to have suppressive effects on inflammatory factors in depressed patients who exhibited increased serum levels of major inflammatory cytokines such as IL-6, IL- $1 \beta$, and TNF- $\alpha$ [111]. The anti-inflammatory role of SSRIs was further supported by a clinical study on 98 depressed patients which found that treatment with either fluoxetine or escitalopram for 2 months significantly reduced inflammatory markers [110]. Notably, TRD patients treated with rTMS had gradually attenuated serum levels of pro-inflammatory IL-1 $\beta$ and TNF- $\alpha$ accompanied by positive changes in Hamilton Depression Rating Scale-24 scores [103]. Moreover, rTMS exerted antidepressant-like effects in a CUMS model via a nuclear factor-E2-related factor 2 (Nrf2)-dependent anti-inflammatory mechanism, which suppressed the production of proinflammatory TNF- $\alpha$, iNOS, IL-1 $\beta$, and IL-6 in hippocampal regions [112]. A substantial body of evidence consistently showed that ECT could alleviate pro-inflammatory cytokine secretion in depressed patients, as indicated by a notable reduction in peripheral TNF $\alpha$, IL-6, eotaxin-3, and IL-5 levels [113,114,116,117]. Moreover, ECT was also reported to increase the level of blood IL-10 [115], which is a well-established anti-inflammatory cytokine that prevents neuronal and glial cell death [128]. Given that TES was demonstrated to reduce inflammatory responses via regulating cytokine expression and suppressing microglial activation [39,42-44], its putative anti-depressant effects on inflammation warrant investigation in the future.

\section{Benefits and Risks of TES As a Depression Treatment}

A major advantage of TES is that it is a non-invasive, reversible, and highly adjustable stimulation method. Numerous pre-clinical and clinical studies demonstrated an excellent safety profile of TES and no serious adverse side effects were reported. On the contrary, invasive neuromodulation approaches such as deep brain stimulation carry a risk of infection and haemorrhage during invasive neurosurgery [129-131]. Moreover, there is a risk of seizure during stimulation in rTMZ [132], while ECT has potential cognitive side effects including retrograde and anterograde amnesia $[133,134]$. Compared with conventional antidepressant drugs that affect the entire body, TES can deliver its effects in specifically targeted brain regions [135]. Furthermore, TES avoids the common side effects of antidepressants such as weight change, hepatotoxicity, and gastrointestinal problems $[136,137]$. The adjustable nature of TES allows the stimulation parameters to be fine-tuned depending on the individual patient's condition and disease progression. The stimulator can be quickly turned off if an adverse event occurs and the stimulating electrodes can be easily removed. Additionally, the simple administration of TES could 
allow for self-administration by patients, which greatly enhances its flexibility throughout the treatment period [138].

Although TES is well tolerated in humans with only mild and transient side effects, even after prolonged use, there are some commonly observed side effects, including foreign body sensation, dry eye symptoms, and corneal punctate keratopathy, which can be mostly resolved without further treatment [76,138-140]. Other infrequent adverse events include unilateral cataracts, the sensation of flashing lights, muscle twitching, vomiting, and a tingling sensation on the side of the head [138]. Moreover, there were two reported cases of retinal perforation in rats, possibly as a result of mechanical pressure or high charge density stimulation [36]. Considering the potential ocular damage caused by high amplitude stimulation, the optimal stimulation parameters need to be well validated. Furthermore, both antidepressant-like and depressive-like behaviour was reported in the corneal kindling model, and it raised the possibility that TES could resolve or exacerbate depressive-like symptoms. It is therefore important to examine the therapeutic effects of TES using an animal model of depression with proper control, and further investigate of the putative TES-induced activation in brain structures associated with depression in order to delineate the underlying mechanisms of action.

\section{Conclusions}

As an emerging non-invasive neuromodulation approach, TES shows promising neuroprotective properties involving neurotrophic, neuroplasticity, anti-apoptosis, antiinflammatory, anti-glutamatergic, and vasodilation mechanisms. Although the beneficial effects of TES in visual restoration are widely reported, its putative neuroprotective effects remain largely unexplored. The above studies show that TES can activate brain regions specifically involved in mood alteration. Some studies show that it can induce antidepressant-like behaviour in corneally kindled models, raising the possibility of using TES in emotional regulation. The hypothesis that ophthalmological treatments can also exert beneficial effects on mood disorders is further supported not only by the interconnections between visual and emotional pathways, but also by the bidirectional association between visual impairment and depression. Here, we speculate that TES may exert antidepressantlike activities similar to some FDA-approved depression treatments including SSRIs, rTMS, and ECT, which are consistently shown to target neurotrophic expression, apoptosis, and inflammatory processes in the nervous system. This review provides evidence of the potential antidepressant effects of TES to encourage further investigations into the therapeutic use of TES in treating depression. Nevertheless, the potential neuroprotective effects of TES need to be properly evaluated in preclinical animal models of depression and in clinical human trials to ensure its safe application and efficacy in depressed populations.

Author Contributions: Conceptualization, original draft preparation, and revision: W.-S.Y., S.-H.K. and L.-W.L.; data collection and preparation of tables/figures: W.-S.Y. and S.-H.K.; supervision, funding acquisition, and manuscript editing: L.-W.L.; intellectual inputs and manuscript review: S.K.A., L.-L.-H.C. and K.-H.W. All authors have read and agreed to the published version of the manuscript.

Funding: The scientific work was funded by the Hong Kong Research Grant Council (Ref.: 17119420), and the University of Hong Kong's Seed Fund for Translational and Applied Research (Ref.: 201910160010) awarded to LWL. The scientific work was fully conducted at the Neuromodulation Laboratory (www.drlimlab.com), the University of Hong Kong.

Conflicts of Interest: The authors declare no conflict of interest.

\section{References}

1. WHO. WHO Depression Fact Sheet; World Health Organization (WHO): Geneva, Switzerland, 2020.

2. WHO. Depression and Other Common Mental Disorders: Global Health Estimates; World Health Organization (WHO): Geneva, Switzerland, 2017.

3. Greenberg, P.E.; Fournier, A.A.; Sisitsky, T.; Simes, M.; Berman, R.; Koenigsberg, S.H.; Kessler, R.C. The Economic Burden of Adults with Major Depressive Disorder in the United States (2010 and 2018). Pharmacoeconomics 2021, 39, 653-665. [CrossRef] [PubMed] 
4. Association, A.P. Diagnostic and Statistical Manual of Mental Disorders (DSM- $5^{\circledR}$ ); American Psychiatric Pub: Arlington, VA, USA, 2013.

5. Kang, H.-J.; Kim, S.-Y.; Bae, K.-Y.; Kim, S.-W.; Shin, I.-S.; Yoon, J.-S.; Kim, J.-M. Comorbidity of depression with physical disorders: Research and clinical implications. Chonnam. Med. J. 2015, 51, 8-18. [CrossRef] [PubMed]

6. Kroenke, K.; Wu, J.; Bair, M.J.; Krebs, E.E.; Damush, T.M.; Tu, W. Reciprocal relationship between pain and depression: A 12-month longitudinal analysis in primary care. J. Pain 2011, 12, 964-973. [CrossRef] [PubMed]

7. Stubbs, B.; Vancampfort, D.; Veronese, N.; Thompson, T.; Fornaro, M.; Schofield, P.; Solmi, M.; Mugisha, J.; Carvalho, A.F.; Koyanagi, A. Depression and pain: Primary data and meta-analysis among 237,952 people across 47 low-and middle-income countries. Psychol. Med. 2017, 47, 2906-2917. [CrossRef] [PubMed]

8. Byers, A.L.; Yaffe, K. Depression and risk of developing dementia. Nat. Rev. Neurol. 2011, 7, 323-331. [CrossRef]

9. Knol, M.; Twisk, J.W.; Beekman, A.T.; Heine, R.; Snoek, F.J.; Pouwer, F. Depression as a risk factor for the onset of type 2 diabetes mellitus. A meta-analysis. Diabetologia 2006, 49, 837. [CrossRef] [PubMed]

10. Bădescu, S.V.; Tătaru, C.; Kobylinska, L.; Georgescu, E.L.; Zahiu, D.M.; Zăgrean, A.M.; Zăgrean, L. The association between Diabetes mellitus and Depression. J. Med. Life 2016, 9, 120-125.

11. Van der Kooy, K.; van Hout, H.; Marwijk, H.; Marten, H.; Stehouwer, C.; Beekman, A. Depression and the risk for cardiovascular diseases: Systematic review and meta analysis. Int J. Geriatr. Psychiatry 2007, 22, 613-626. [CrossRef]

12. Khawaja, I.S.; Westermeyer, J.J.; Gajwani, P.; Feinstein, R.E. Depression and coronary artery disease: The association, mechanisms, and therapeutic implications. Psychiatry 2009, 6, 38-51.

13. Gump, B.B.; Matthews, K.A.; Eberly, L.E.; Chang, Y.F.; Group, M.R. Depressive symptoms and mortality in men: Results from the Multiple Risk Factor Intervention Trial. Stroke 2005, 36, 98-102. [CrossRef]

14. Pan, A.; Sun, Q.; Okereke, O.I.; Rexrode, K.M.; Hu, F.B. Depression and risk of stroke morbidity and mortality: A meta-analysis and systematic review. JAMA 2011, 306, 1241-1249. [CrossRef]

15. Spiegel, D.; Giese-Davis, J. Depression and cancer: Mechanisms and disease progression. Biol. Psychiatry 2003, 54, 269-282. [CrossRef]

16. Hillhouse, T.M.; Porter, J.H. A brief history of the development of antidepressant drugs: From monoamines to glutamate. Exp. Clin. Psychopharmacol. 2015, 23, 1-21. [CrossRef]

17. Al-Harbi, K.S. Treatment-resistant depression: Therapeutic trends, challenges, and future directions. Patient Prefer. Adherence 2012, 6, 369. [CrossRef]

18. Mrazek, D.A.; Hornberger, J.C.; Altar, C.A.; Degtiar, I. A review of the clinical, economic, and societal burden of treatment-resistant depression: 1996-2013. Psychiatr. Serv. 2014, 65, 977-987. [CrossRef] [PubMed]

19. Morishita, T.; Fayad, S.M.; Higuchi, M.-A.; Nestor, K.A.; Foote, K.D. Deep brain stimulation for treatment-resistant depression: Systematic review of clinical outcomes. Neurotherapeutics 2014, 11, 475-484. [CrossRef]

20. Temel, Y.; Hescham, S.A.; Jahanshahi, A.; Janssen, M.L.; Tan, S.K.; van Overbeeke, J.J.; Ackermans, L.; Oosterloo, M.; Duits, A.; Leentjens, A.F.; et al. Neuromodulation in psychiatric disorders. Int. Rev. Neurobiol. 2012, 107, 283-314. [CrossRef]

21. Kolshus, E.; Jelovac, A.; McLoughlin, D. Bitemporal v. high-dose right unilateral electroconvulsive therapy for depression: A systematic review and meta-analysis of randomized controlled trials. Psychol. Med. 2017, 47, 518-530. [CrossRef]

22. Brus, O.; Cao, Y.; Gustafsson, E.; Hultén, M.; Landen, M.; Lundberg, J.; Nordanskog, P.; Nordenskjöld, A. Self-assessed remission rates after electroconvulsive therapy of depressive disorders. Eur. Psychiatry 2017, 45, 154-160. [CrossRef] [PubMed]

23. Bahji, A.; Hawken, E.; Sepehry, A.; Cabrera, C.; Vazquez, G. ECT beyond unipolar major depression: Systematic review and meta-Analysis of electroconvulsive therapy in bipolar depression. Acta Psychiatr. Scand. 2019, 139, 214-226. [CrossRef]

24. Tokutsu, Y.; Umene-Nakano, W.; Shinkai, T.; Yoshimura, R.; Okamoto, T.; Katsuki, A.; Hori, H.; Ikenouchi-Sugita, A.; Hayashi, K.; Atake, K. Follow-up study on electroconvulsive therapy in treatment-resistant depressed patients after remission: A chart review. Clin. Psychopharmacol. Neurosci. 2013, 11,34. [CrossRef] [PubMed]

25. Jelovac, A.; Kolshus, E.; McLoughlin, D.M. Relapse following successful electroconvulsive therapy for major depression: A meta-analysis. Neuropsychopharmacology 2013, 38, 2467-2474. [CrossRef]

26. Krames, E.S.; Peckham, P.H.; Rezai, A.; Aboelsaad, F. What is neuromodulation? In Neuromodulation; Elsevier: Amsterdam, The Netherlands, 2009; pp. 3-8.

27. Tao, Y.; Chen, T.; Liu, B.; Wang, L.-Q.; Peng, G.-H.; Qin, L.-M.; Yan, Z.-J.; Huang, Y.-F. The transcorneal electrical stimulation as a novel therapeutic strategy against retinal and optic neuropathy: A review of experimental and clinical trials. Int. J. Ophthalmol. 2016, 9, 914. [PubMed]

28. Wlaź, P.; Poleszak, E.; Serefko, A.; Wlaź, A.; Rundfeldt, C. Anxiogenic-and antidepressant-like behavior in corneally kindled rats. Pharmacol. Rep. 2015, 67, 349-352. [CrossRef] [PubMed]

29. Xie, J.; Wang, G.-J.; Yow, L.; Cela, C.J.; Humayun, M.S.; Weiland, J.D.; Lazzi, G.; Jadvar, H. Modeling and percept of transcorneal electrical stimulation in humans. IEEE Trans. Biomed. Eng. 2011, 58, 1932-1939. [CrossRef] [PubMed]

30. Agadagba, S.K.; Li, X.; Chan, L.L. Electroencephalogram power alterations in retinal degeneration mice after prolonged transcorneal electrical stimulation. In Proceedings of the 2019 9th International IEEE/EMBS Conference on Neural Engineering (NER), Manhattan, NY, USA, 2019; pp. 219-222.

31. Agadagba, S.K.; Li, X.; Chan, L.L.H. Excitation of the Pre-frontal and Primary Visual Cortex in Response to Transcorneal Electrical Stimulation in Retinal Degeneration Mice. Front. Neurosci. 2020, 14, 572299:1-572299:13. [CrossRef] 
32. Habel, U.; Klein, M.; Kellermann, T.; Shah, N.J.; Schneider, F. Same or different? Neural correlates of happy and sad mood in healthy males. Neuroimage 2005, 26, 206-214. [CrossRef]

33. Sergeeva, E.G.; Fedorov, A.B.; Henrich-Noack, P.; Sabel, B.A. Transcorneal alternating current stimulation induces EEG "aftereffects" only in rats with an intact visual system but not after severe optic nerve damage. J. Neurophysiol. 2012, 108, $2494-2500$. [CrossRef]

34. Morimoto, T.; Miyoshi, T.; Matsuda, S.; Tano, Y.; Fujikado, T.; Fukuda, Y. Transcorneal electrical stimulation rescues axotomized retinal ganglion cells by activating endogenous retinal IGF-1 system. Investig. Ophthalmol. Vis. Sci. 2005, 46, 2147-2155. [CrossRef]

35. Tagami, Y.; Kurimoto, T.; Miyoshi, T.; Morimoto, T.; Sawai, H.; Mimura, O. Axonal regeneration induced by repetitive electrical stimulation of crushed optic nerve in adult rats. Jpn. J. Ophthalmol. 2009, 53, 257-266. [CrossRef]

36. Ni, Y.-Q.; Gan, D.-K.; Xu, H.-D.; Xu, G.-Z. Neuroprotective effect of transcorneal electrical stimulation on light-induced photoreceptor degeneration. Exp. Neurol. 2009, 219, 439-452. [CrossRef]

37. Sato, T.; Fujikado, T.; Morimoto, T.; Matsushita, K.; Harada, T.; Tano, Y. Effect of electrical stimulation on IGF-1 transcription by L-type calcium channels in cultured retinal Müller cells. Jpn. J. Ophthalmol. 2008, 52, 217-223. [CrossRef] [PubMed]

38. Sato, T.; Fujikado, T.; Lee, T.-S.; Tano, Y. Direct effect of electrical stimulation on induction of brain-derived neurotrophic factor from cultured retinal Muller cells. Investig. Ophthalmol. Vis. Sci. 2008, 49, 4641-4646. [CrossRef] [PubMed]

39. Zhou, W.-T.; Ni, Y.-Q.; Jin, Z.-B.; Zhang, M.; Wu, J.-H.; Zhu, Y.; Xu, G.-Z.; Gan, D.-K. Electrical stimulation ameliorates light-induced photoreceptor degeneration in vitro via suppressing the proinflammatory effect of microglia and enhancing the neurotrophic potential of Müller cells. Exp. Neurol. 2012, 238, 192-208. [CrossRef] [PubMed]

40. Enayati, S.; Chang, K.; Achour, H.; Cho, K.-S.; Xu, F.; Guo, S.; Enayati, K.Z.; Xie, J.; Zhao, E.; Turunen, T. Electrical stimulation induces retinal müller cell proliferation and their progenitor cell potential. Cells 2020, 9, 781. [CrossRef]

41. Langmann, T. Microglia activation in retinal degeneration. J. Leukoc. Biol. 2007, 81, 1345-1351. [CrossRef]

42. Fu, L.; Fung, F.K.; Lo, A.C.-Y.; Chan, Y.-K.; So, K.-F.; Wong, I.Y.-H.; Shih, K.C.; Lai, J.S.-M. Transcorneal electrical stimulation inhibits retinal microglial activation and enhances retinal ganglion cell survival after acute ocular hypertensive injury. Transl. Vis. Sci. Technol. 2018, 7, 7. [CrossRef]

43. Yin, H.; Yin, H.; Zhang, W.; Miao, Q.; Qin, Z.; Guo, S.; Fu, Q.; Ma, J.; Wu, F.; Yin, J. Transcorneal electrical stimulation promotes survival of retinal ganglion cells after optic nerve transection in rats accompanied by reduced microglial activation and TNF- $\alpha$ expression. Brain Res. 2016, 1650, 10-20. [CrossRef]

44. Jassim, A.H.; Cavanaugh, M.; Shah, J.S.; Willits, R.; Inman, D.M. Transcorneal Electrical Stimulation Reduces Neurodegenerative Process in a Mouse Model of Glaucoma. Ann. Biomed. Eng. 2021, 49, 858-870. [CrossRef]

45. Willmann, G.; Schäferhoff, K.; Fischer, M.D.; Arango-Gonzalez, B.; Bolz, S.; Naycheva, L.; Röck, T.; Bonin, M.; Bartz-Schmidt, K.U.; Zrenner, E. Gene expression profiling of the retina after transcorneal electrical stimulation in wild-type Brown Norway rats. Investig. Ophthalmol. Vis. Sci. 2011, 52, 7529-7537. [CrossRef]

46. Tao, Y.; Chen, T.; Liu, Z.-Y.; Wang, L.-Q.; Xu, W.-W.; Qin, L.-M.; Peng, G.-H.; Yi-Fei, H. Topographic Quantification of the Transcorneal Electrical Stimulation (TES)-Induced Protective Effects on N-Methyl-N-Nitrosourea-Treated Retinas. Investig. Ophthalmol. Vis. Sci. 2016, 57, 4614-4624. [CrossRef]

47. Momeni, H.R. Role of calpain in apoptosis. Cell J. 2011, 13, 65.

48. Wang, X.; Mo, X.; Li, D.; Wang, Y.; Fang, Y.; Rong, X.; Miao, H.; Shou, T. Neuroprotective effect of transcorneal electrical stimulation on ischemic damage in the rat retina. Exp. Eye Res. 2011, 93, 753-760. [CrossRef]

49. Kurimoto, T.; Oono, S.; Oku, H.; Tagami, Y.; Kashimoto, R.; Takata, M.; Okamoto, N.; Ikeda, T.; Mimura, O. Transcorneal electrical stimulation increases chorioretinal blood flow in normal human subjects. Clin. Ophthalmol. 2010, 4, 1441. [CrossRef]

50. Bittner, A.K.; Seger, K.; Salveson, R.; Kayser, S.; Morrison, N.; Vargas, P.; Mendelsohn, D.; Han, J.; Bi, H.; Dagnelie, G. Randomized controlled trial of electro-Stimulation therapies to modulate retinal blood flow and visual function in retinitis pigmentosa. Acta Ophthalmol. 2018, 96, e366-e376. [CrossRef] [PubMed]

51. Silverstein, D.N.; Ingvar, M. A multi-pathway hypothesis for human visual fear signaling. Front. Syst. Neurosci. $2015,9,101$. [CrossRef]

52. McFadyen, J.; Mattingley, J.B.; Garrido, M.I. An afferent white matter pathway from the pulvinar to the amygdala facilitates fear recognition. Elife 2019, 8, e40766. [CrossRef] [PubMed]

53. Diederich, N.J.; Stebbins, G.; Schiltz, C.; Goetz, C.G. Are patients with Parkinson's disease blind to blindsight? Brain 2014, 137, 1838-1849. [CrossRef]

54. Pessoa, L.; Adolphs, R. Emotion processing and the amygdala: From a'low road'to'many roads' of evaluating biological significance. Nat. Rev. Neurosci. 2010, 11, 773-782. [CrossRef] [PubMed]

55. Tsanov, M.; Manahan-Vaughan, D. Synaptic plasticity from visual cortex to hippocampus: Systems integration in spatial information processing. Neuroscientist 2008, 14, 584-597. [CrossRef] [PubMed]

56. Bird, C.M.; Burgess, N. The hippocampus and memory: Insights from spatial processing. Nat. Rev. Neurosci. 2008, 9, 182-194. [CrossRef] [PubMed]

57. Veneri, G.; Federico, A.; Rufa, A. Evaluating the influence of motor control on selective attention through a stochastic model: The paradigm of motor control dysfunction in cerebellar patient. BioMed Res. Int. 2014, 2014, 162423:1-162423:13. [CrossRef] [PubMed]

58. Jin, J.; Maren, S. Prefrontal-hippocampal interactions in memory and emotion. Front. Syst. Neurosci. 2015, 9, 170. [CrossRef] 
59. Zheng, Y.; Wu, X.; Lin, X.; Lin, H. The prevalence of depression and depressive symptoms among eye disease patients: A systematic review and meta-analysis. Sci. Rep. 2017, 7, 46453. [CrossRef] [PubMed]

60. Choi, H.G.; Lee, M.J.; Lee, S.M. Visual impairment and risk of depression: A longitudinal follow-up study using a national sample cohort. Sci. Rep. 2018, 8, 2083. [CrossRef]

61. Hahm, B.-J.; Shin, Y.-W.; Shim, E.-J.; Jeon, H.J.; Seo, J.-M.; Chung, H.; Yu, H.G. Depression and the vision-related quality of life in patients with retinitis pigmentosa. Br. J. Ophthalmol. 2008, 92, 650-654. [CrossRef]

62. Frank, C.R.; Xiang, X.; Stagg, B.C.; Ehrlich, J.R. Longitudinal associations of self-reported vision impairment with symptoms of anxiety and depression among older adults in the United States. JAMA Ophthalmol. 2019, 137, 793-800. [CrossRef] [PubMed]

63. Morimoto, T.; Miyoshi, T.; Sawai, H.; Fujikado, T. Optimal parameters of transcorneal electrical stimulation (TES) to be neuroprotective of axotomized RGCs in adult rats. Exp. Eye Res. 2010, 90, 285-291. [CrossRef]

64. Henrich-Noack, P.; Lazik, S.; Sergeeva, E.; Wagner, S.; Voigt, N.; Prilloff, S.; Fedorov, A.; Sabel, B.A. Transcorneal alternating current stimulation after severe axon damage in rats results in "long-term silent survivor" neurons. Brain Res. Bull. 2013, 95, 7-14. [CrossRef]

65. Henrich-Noack, P.; Voigt, N.; Prilloff, S.; Fedorov, A.; Sabel, B.A. Transcorneal electrical stimulation alters morphology and survival of retinal ganglion cells after optic nerve damage. Neurosci. Lett. 2013, 543, 1-6. [CrossRef]

66. Miyake, K.-I.; Yoshida, M.; Inoue, Y.; Hata, Y. Neuroprotective effect of transcorneal electrical stimulation on the acute phase of optic nerve injury. Investig. Ophthalmol. Vis. Sci. 2007, 48, 2356-2361. [CrossRef]

67. Osako, T.; Chuman, H.; Maekubo, T.; Ishiai, M.; Kawano, N.; Nao-i, N. Effects of steroid administration and transcorneal electrical stimulation on the anatomic and electrophysiologic deterioration of nonarteritic ischemic optic neuropathy in a rodent model. Jpn. J. Ophthalmol. 2013, 57, 410-415. [CrossRef]

68. Morimoto, T.; Fujikado, T.; Choi, J.-S.; Kanda, H.; Miyoshi, T.; Fukuda, Y.; Tano, Y. Transcorneal electrical stimulation promotes the survival of photoreceptors and preserves retinal function in royal college of surgeons rats. Investig. Ophthalmol. Vis. Sci. 2007, 48, 4725-4732. [CrossRef] [PubMed]

69. Morimoto, T.; Kanda, H.; Kondo, M.; Terasaki, H.; Nishida, K.; Fujikado, T. Transcorneal electrical stimulation promotes survival of photoreceptors and improves retinal function in rhodopsin P347L transgenic rabbits. Investig. Ophthalmol. Vis. Sci. 2012, 53, 4254-4261. [CrossRef]

70. Rahmani, S.; Bogdanowicz, L.; Thomas, J.; Hetling, J.R. Chronic delivery of low-level exogenous current preserves retinal function in pigmented $\mathrm{P} 23 \mathrm{H}$ rat. Vis. Res. 2013, 76, 105-113. [CrossRef] [PubMed]

71. Schatz, A.; Röck, T.; Naycheva, L.; Willmann, G.; Wilhelm, B.; Peters, T.; Bartz-Schmidt, K.U.; Zrenner, E.; Messias, A.; Gekeler, F. Transcorneal electrical stimulation for patients with retinitis pigmentosa: A prospective, randomized, sham-controlled exploratory study. Investig. Ophthalmol. Vis. Sci. 2011, 52, 4485-4496. [CrossRef]

72. Schatz, A.; Pach, J.; Gosheva, M.; Naycheva, L.; Willmann, G.; Wilhelm, B.; Peters, T.; Bartz-Schmidt, K.U.; Zrenner, E.; Messias, A. Transcorneal electrical stimulation for patients with retinitis pigmentosa: A prospective, randomized, sham-controlled follow-up study over 1 year. Investig. Ophthalmol. Vis. Sci. 2017, 58, 257-269. [CrossRef] [PubMed]

73. Naycheva, L.; Schatz, A.; Willmann, G.; Bartz-Schmidt, K.U.; Zrenner, E.; Röck, T.; Gekeler, F. Transcorneal electrical stimulation in patients with retinal artery occlusion: A prospective, randomized, sham-controlled pilot study. Ophthalmol. Ther. 2013, 2, 25-39. [CrossRef] [PubMed]

74. Inomata, K.; Shinoda, K.; Ohde, H.; Tsunoda, K.; Hanazono, G.; Kimura, I.; Yuzawa, M.; Tsubota, K.; Miyake, Y. Transcorneal electrical stimulation of retina to treat longstanding retinal artery occlusion. Graefe's Arch. Clin. Exp. Ophthalmol. 2007, 245, 1773-1780. [CrossRef] [PubMed]

75. Oono, S.; Kurimoto, T.; Kashimoto, R.; Tagami, Y.; Okamoto, N.; Mimura, O. Transcorneal electrical stimulation improves visual function in eyes with branch retinal artery occlusion. Clin. Ophthalmol. 2011, 5, 397.

76. Fujikado, T.; Morimoto, T.; Matsushita, K.; Shimojo, H.; Okawa, Y.; Tano, Y. Effect of transcorneal electrical stimulation in patients with nonarteritic ischemic optic neuropathy or traumatic optic neuropathy. Jpn. J. Ophthalmol. 2006, 50, 266-273. [CrossRef]

77. Huang, E.J.; Reichardt, L.F. Neurotrophins: Roles in neuronal development and function. Annu. Rev. Neurosci. 2001, 24, 677-736. [CrossRef]

78. Sabel, B.A.; Fedorov, A.B.; Naue, N.; Borrmann, A.; Herrmann, C.; Gall, C. Non-invasive alternating current stimulation improves vision in optic neuropathy. Restor. Neurol. Neurosci. 2011, 29, 493-505. [CrossRef] [PubMed]

79. Foik, A.T.; Kublik, E.; Sergeeva, E.G.; Tatlisumak, T.; Rossini, P.M.; Sabel, B.A.; Waleszczyk, W.J. Retinal origin of electrically evoked potentials in response to transcorneal alternating current stimulation in the rat. Investig. Ophthalmol. Vis. Sci. 2015, 56, 1711-1718. [CrossRef] [PubMed]

80. Osborne, N.N.; Casson, R.J.; Wood, J.P.; Chidlow, G.; Graham, M.; Melena, J. Retinal ischemia: Mechanisms of damage and potential therapeutic strategies. Prog. Retin. Eye Res. 2004, 23, 91-147. [CrossRef] [PubMed]

81. Ishikawa, M. Abnormalities in glutamate metabolism and excitotoxicity in the retinal diseases. Scientifica 2013, 2013, 528940:1528940:13. [CrossRef] [PubMed]

82. Muniyappa, R.; Walsh, M.; Rangi, J.; Zayas, R.; Standley, P.R.; Ram, J.; Sowers, J. Insulin like growth factor 1 increases vascular smooth muscle nitric oxide production. Life Sci. 1997, 61, 925-931. [CrossRef]

83. Haylor, J.; Singh, I.; El Nahas, A.M. Nitric oxide synthesis inhibitor prevents vasodilation by insulin-like growth factor I. Kidney Int. 1991, 39, 333-335. [CrossRef] [PubMed] 
84. Atalay, B.; Bolay, H.; Dalkara, T.; Soylemezoglu, F.; Oge, K.; Ozcan, O.E. Transcorneal stimulation of trigeminal nerve afferents to increase cerebral blood flow in rats with cerebral vasospasm: A noninvasive method to activate the trigeminovascular reflex. $J$. Neurosurg. 2002, 97, 1179-1183. [CrossRef] [PubMed]

85. Mayberg, H.S.; Brannan, S.K.; Tekell, J.L.; Silva, J.A.; Mahurin, R.K.; McGinnis, S.; Jerabek, P.A. Regional metabolic effects of fluoxetine in major depression: Serial changes and relationship to clinical response. Biol. Psychiatry 2000, 48, 830-843. [CrossRef]

86. Brody, A.L.; Saxena, S.; Mandelkern, M.A.; Fairbanks, L.A.; Ho, M.L.; Baxter, L.R. Brain metabolic changes associated with symptom factor improvement in major depressive disorder. Biol. Psychiatry 2001, 50, 171-178. [CrossRef]

87. Lévesque, J.; Eugène, F.; Joanette, Y.; Paquette, V.; Mensour, B.; Beaudoin, G.; Leroux, J.-M.; Bourgouin, P.; Beauregard, M. Neural circuitry underlying voluntary suppression of sadness. Biol. Psychiatry 2003, 53, 502-510. [CrossRef]

88. Phan, K.L.; Fitzgerald, D.A.; Nathan, P.J.; Moore, G.J.; Uhde, T.W.; Tancer, M.E. Neural substrates for voluntary suppression of negative affect: A functional magnetic resonance imaging study. Biol. Psychiatry 2005, 57, 210-219. [CrossRef]

89. Zeng, L.-L.; Shen, H.; Liu, L.; Wang, L.; Li, B.; Fang, P.; Zhou, Z.; Li, Y.; Hu, D. Identifying major depression using whole-brain functional connectivity: A multivariate pattern analysis. Brain 2012, 135, 1498-1507. [CrossRef] [PubMed]

90. Albertini, G.; Walrave, L.; Demuyser, T.; Massie, A.; De Bundel, D.; Smolders, I. 6 Hz corneal kindling in mice triggers neurobehavioral comorbidities accompanied by relevant changes in c-Fos immunoreactivity throughout the brain. Epilepsia 2018, 59, 67-78. [CrossRef] [PubMed]

91. Koshal, P.; Kumar, P. Effect of liraglutide on corneal kindling epilepsy induced depression and cognitive impairment in mice. Neurochem. Res. 2016, 41, 1741-1750. [CrossRef]

92. Dwyer, J.B.; Bloch, M.H. Antidepressants for pediatric patients. Curr. Psychiatr. 2019, 18, 26. [PubMed]

93. Segi-Nishida, E. The effect of serotonin-targeting antidepressants on neurogenesis and neuronal maturation of the hippocampus mediated via 5-HT1A and 5-HT4 receptors. Front. Cell. Neurosci. 2017, 11, 142. [CrossRef]

94. Hardy, S.; Bastick, L.; O’Neill-Kerr, A.; Sabesan, P.; Lankappa, S.; Palaniyappan, L. Transcranial magnetic stimulation in clinical practice. BJPsych Adv. 2016, 22, 373-379. [CrossRef]

95. Turi, Z.; Normann, C.; Domschke, K.; Vlachos, A. Transcranial magnetic stimulation in psychiatry: Is there a need for electric field standardization? Front. Hum. Neurosci. 2021, 15, 639640:1-639640:7. [CrossRef]

96. Salik, I.; Marwaha, R. Electroconvulsive Therapy. In StatPearls; StatPearls Publishing: Treasure Island, FL, USA, 2021.

97. Cattaneo, A.; Bocchio-Chiavetto, L.; Zanardini, R.; Milanesi, E.; Placentino, A.; Gennarelli, M. Reduced peripheral brain-derived neurotrophic factor mRNA levels are normalized by antidepressant treatment. Int. J. Neuropsychopharmacol. 2010, 13, 103-108. [CrossRef]

98. Martocchia, A.; Curto, M.; Scaccianoce, S.; Comite, F.; Xenos, D.; Nasca, C.; Falaschi, G.M.; Ferracuti, S.; Girardi, P.; Nicoletti, F. Effects of escitalopram on serum BDNF levels in elderly patients with depression: A preliminary report. Aging Clin. Exp. Res. 2014, 26, 461-464. [CrossRef]

99. Zanardini, R.; Gazzoli, A.; Ventriglia, M.; Perez, J.; Bignotti, S.; Rossini, P.M.; Gennarelli, M.; Bocchio-Chiavetto, L. Effect of repetitive transcranial magnetic stimulation on serum brain derived neurotrophic factor in drug resistant depressed patients. $J$. Affect. Disord. 2006, 91, 83-86. [CrossRef]

100. Yukimasa, T.; Yoshimura, R.; Tamagawa, A.; Uozumi, T.; Shinkai, K.; Ueda, N.; Tsuji, S.; Nakamura, J. High-frequency repetitive transcranial magnetic stimulation improves refractory depression by influencing catecholamine and brain-derived neurotrophic factors. Pharmacopsychiatry 2006, 39, 52-59. [CrossRef] [PubMed]

101. Feng, S.-F.; Shi, T.-Y.; Wang, W.-N.; Chen, Y.-C.; Tan, Q.-R. Long-lasting effects of chronic rTMS to treat chronic rodent model of depression. Behav. Brain Res. 2012, 232, 245-251. [CrossRef] [PubMed]

102. Wang, H.-N.; Wang, L.; Zhang, R.-G.; Chen, Y.-C.; Liu, L.; Gao, F.; Nie, H.; Hou, W.-G.; Peng, Z.-W.; Tan, Q. Anti-depressive mechanism of repetitive transcranial magnetic stimulation in rat: The role of the endocannabinoid system. J. Psychiatr. Res. 2014, 51, 79-87. [CrossRef]

103. Zhao, X.; Li, Y.; Tian, Q.; Zhu, B.; Zhao, Z. Repetitive transcranial magnetic stimulation increases serum brain-derived neurotrophic factor and decreases interleukin- $1 \beta$ and tumor necrosis factor- $\alpha$ in elderly patients with refractory depression. J. Int. Med Res. 2019, 47, 1848-1855. [CrossRef] [PubMed]

104. Taliaz, D.; Nagaraj, V.; Haramati, S.; Chen, A.; Zangen, A. Altered brain-derived neurotrophic factor expression in the ventral tegmental area, but not in the hippocampus, is essential for antidepressant-like effects of electroconvulsive therapy. Biol. Psychiatry 2013, 74, 305-312. [CrossRef]

105. Brunoni, A.R.; Baeken, C.; Machado-Vieira, R.; Gattaz, W.F.; Vanderhasselt, M.-A. BDNF blood levels after electroconvulsive therapy in patients with mood disorders: A systematic review and meta-analysis. World J. Biol. Psychiatry 2014, 15, 411-418. [CrossRef] [PubMed]

106. Vanicek, T.; Kranz, G.S.; Vyssoki, B.; Fugger, G.; Komorowski, A.; Höflich, A.; Saumer, G.; Milovic, S.; Lanzenberger, R.; Eckert, A. Acute and subsequent continuation electroconvulsive therapy elevates serum BDNF levels in patients with major depression. Brain Stimul. 2019, 12, 1041-1050. [CrossRef]

107. Kosten, T.A.; Galloway, M.P.; Duman, R.S.; Russell, D.S.; D'sa, C. Repeated unpredictable stress and antidepressants differentially regulate expression of the bcl-2 family of apoptotic genes in rat cortical, hippocampal, and limbic brain structures. Neuropsychopharmacology 2008, 33, 1545-1558. [CrossRef] [PubMed] 
108. Yang, Y.; Hu, Z.; Du, X.; Davies, H.; Huo, X.; Fang, M. miR-16 and fluoxetine both reverse autophagic and apoptotic change in chronic unpredictable mild stress model rats. Front. Neurosci. 2017, 11, 428. [CrossRef] [PubMed]

109. Zhao, L.; Ren, H.; Gu, S.; Li, X.; Jiang, C.; Li, J.; Zhang, M.; Mu, J.; Li, W.; Wang, W. rTMS ameliorated depressive-like behaviors by restoring HPA axis balance and prohibiting hippocampal neuron apoptosis in a rat model of depression. Psychiatry Res. 2018, 269, 126-133. [CrossRef] [PubMed]

110. Chavda, N.; Kantharia, N.; Charan, J. Effects of fluoxetine and escitalopram on C-reactive protein in patients of depression. J. Pharmacol. Pharmacother. 2011, 2, 11-16. [CrossRef]

111. Hannestad, J.; DellaGioia, N.; Bloch, M. The effect of antidepressant medication treatment on serum levels of inflammatory cytokines: A meta-analysis. Neuropsychopharmacology 2011, 36, 2452-2459. [CrossRef] [PubMed]

112. Tian, L.; Sun, S.-S.; Cui, L.-B.; Wang, S.-Q.; Peng, Z.-W.; Tan, Q.-R.; Hou, W.-G.; Cai, M. Repetitive transcranial magnetic stimulation elicits antidepressant-and anxiolytic-like effect via nuclear factor-E2-related factor 2-mediated anti-inflammation mechanism in rats. Neuroscience 2020, 429, 119-133. [CrossRef]

113. Hestad, K.A.; Tønseth, S.; Støen, C.D.; Ueland, T.; Aukrust, P. Raised plasma levels of tumor necrosis factor $\alpha$ in patients with depression: Normalization during electroconvulsive therapy. J. ECT 2003, 19, 183-188. [CrossRef]

114. Rotter, A.; Biermann, T.; Stark, C.; Decker, A.; Demling, J.; Zimmermann, R.; Sperling, W.; Kornhuber, J.; Henkel, A. Changes of cytokine profiles during electroconvulsive therapy in patients with major depression. J. ECT 2013, 29, 162-169. [CrossRef]

115. Zincir, S.; Öztürk, P.; Bilgen, A.E.; Izci, F.; Yükselir, C. Levels of serum immunomodulators and alterations with electroconvulsive therapy in treatment-resistant major depression. Neuropsychiatr. Dis. Treat. 2016, 12, 1389. [CrossRef]

116. Sorri, A.; Järventausta, K.; Kampman, O.; Lehtimäki, K.; Björkqvist, M.; Tuohimaa, K.; Hämäläinen, M.; Moilanen, E.; Leinonen, E. Low tumor necrosis factor- $\alpha$ levels predict symptom reduction during electroconvulsive therapy in major depressive disorder. Brain Behav. 2018, 8, e00933. [CrossRef]

117. Belge, J.-B.; Van Diermen, L.; Sabbe, B.; Parizel, P.; Morrens, M.; Coppens, V.; Constant, E.; de Timary, P.; Sienaert, P.; Schrijvers, D. Inflammation, Hippocampal Volume, and Therapeutic Outcome following Electroconvulsive Therapy in Depressive Patients: A Pilot Study. Neuropsychobiology 2020, 79, 222-232. [CrossRef]

118. Yang, T.; Nie, Z.; Shu, H.; Kuang, Y.; Chen, X.; Cheng, J.; Yu, S.; Liu, H. The role of BDNF on neural plasticity in depression. Front. Cell. Neurosci. 2020, 14, 82. [CrossRef]

119. Hennigan, A.; O'callaghan, R.; Kelly, A. Neurotrophins and their receptors: Roles in plasticity, neurodegeneration and neuroprotection. Biochem. Soc. Trans. 2007, 35, 424-427. [CrossRef]

120. Bathina, S.; Das, U.N. Brain-derived neurotrophic factor and its clinical implications. Arch. Med Sci. 2015, 11, 1164. [CrossRef] [PubMed]

121. Kim, Y.-K.; Lee, H.-P.; Won, S.-D.; Park, E.-Y.; Lee, H.-Y.; Lee, B.-H.; Lee, S.-W.; Yoon, D.; Han, C.; Kim, D.-J. Low plasma BDNF is associated with suicidal behavior in major depression. Prog. Neuro-Psychopharmacol. Biol. Psychiatry 2007, 31, 78-85. [CrossRef]

122. McKernan, D.P.; Dinan, T.G.; Cryan, J.F. "Killing the Blues": A role for cellular suicide (apoptosis) in depression and the antidepressant response? Prog. Neurobiol. 2009, 88, 246-263. [CrossRef] [PubMed]

123. Duman, R.S. Neuronal damage and protection in the pathophysiology and treatment of psychiatric illness: Stress and depression. Dialogues Clin. Neurosci. 2009, 11, 239. [PubMed]

124. Kale, J.; Osterlund, E.J.; Andrews, D.W. BCL-2 family proteins: Changing partners in the dance towards death. Cell Death Differ. 2018, 25, 65-80. [CrossRef]

125. Pandya, M.; Altinay, M.; Malone, D.A.; Anand, A. Where in the brain is depression? Curr. psychiatry Rep. 2012, 14, 634-642. [CrossRef] [PubMed]

126. Patel, A. The role of inflammation in depression. Psychiatr. Danub. 2013, 25, S216-S223.

127. Gałecki, P.; Talarowska, M. Inflammatory theory of depression. Psychiatr. Pol. 2018, 52, 437-447. [CrossRef] [PubMed]

128. Roque, S.; Correia-Neves, M.; Mesquita, A.R.; Palha, J.A.; Sousa, N. Interleukin-10: A key cytokine in depression? Cardiovasc. Psychiatry Neurol. 2009, 2009, 187894:1-187894:5. [CrossRef]

129. Lozano, A.M.; Lipsman, N.; Bergman, H.; Brown, P.; Chabardes, S.; Chang, J.W.; Matthews, K.; McIntyre, C.C.; Schlaepfer, T.E.; Schulder, M.; et al. Deep brain stimulation: Current challenges and future directions. Nat. Rev. Neurol. 2019, 15, 148-160. [CrossRef] [PubMed]

130. Fenoy, A.J.; Simpson, R.K., Jr. Risks of common complications in deep brain stimulation surgery: Management and avoidance. J. Neurosurg. 2014, 120, 132-139. [CrossRef] [PubMed]

131. Hamurcu, M.S.; Aydogmuş, S.A.; Saricaoğlu, M.S. Evaluation of the efficacy of transcorneal electric stimulation therapy in retinitis pigmentosa patients with electrophysiological and structural tests. Int. J. Clin. Exp. Ophthalmol. 2020, 4, 31-37. [CrossRef]

132. Bae, E.H.; Schrader, L.M.; Machii, K.; Alonso-Alonso, M.; Riviello, J.J., Jr.; Pascual-Leone, A.; Rotenberg, A. Safety and tolerability of repetitive transcranial magnetic stimulation in patients with epilepsy: A review of the literature. Epilepsy Behav. 2007, 10, 521-528. [CrossRef]

133. Brakemeier, E.-L.; Berman, R.; Prudic, J.; Zwillenberg, K.; Sackeim, H.A. Self-evaluation of the cognitive effects of electroconvulsive therapy. J. ECT 2011, 27, 59-66. [CrossRef]

134. Porter, R.J.; Baune, B.T.; Morris, G.; Hamilton, A.; Bassett, D.; Boyce, P.; Hopwood, M.J.; Mulder, R.; Parker, G.; Singh, A.B. Cognitive side-effects of electroconvulsive therapy: What are they, how to monitor them and what to tell patients. BJPsych Open 2020, 6, e40:1-e40:7. [CrossRef] 
135. Holtzheimer, P.E.; Mayberg, H.S. Neuromodulation for treatment-resistant depression. F1000 Med. Rep. 2012, 4. [CrossRef]

136. Uher, R.; Farmer, A.; Henigsberg, N.; Rietschel, M.; Mors, O.; Maier, W.; Kozel, D.; Hauser, J.; Souery, D.; Placentino, A. Adverse reactions to antidepressants. Br. J. Psychiatry 2009, 195, 202-210. [CrossRef]

137. Carvalho, A.F.; Sharma, M.S.; Brunoni, A.R.; Vieta, E.; Fava, G.A. The Safety, Tolerability and Risks Associated with the Use of Newer Generation Antidepressant Drugs: A Critical Review of the Literature. Psychother. Psychosom. 2016, 85, 270-288. [CrossRef] [PubMed]

138. Jolly, J.K.; Wagner, S.K.; Martus, P.; MacLaren, R.E.; Wilhelm, B.; Webster, A.R.; Downes, S.M.; Charbel Issa, P.; Kellner, U.; Jägle, H.; et al. Transcorneal Electrical Stimulation for the Treatment of Retinitis Pigmentosa: A Multicenter Safety Study of the OkuStim ${ }^{\circledR}$ System (TESOLA-Study). Ophthalmic Res. 2020, 63, 234-243. [CrossRef]

139. Morimoto, T.; Fukui, T.; Matsushita, K.; Okawa, Y.; Shimojyo, H.; Kusaka, S.; Tano, Y.; Fujikado, T. Evaluation of residual retinal function by pupillary constrictions and phosphenes using transcorneal electrical stimulation in patients with retinal degeneration. Graefe's Arch. Clin. Exp. Ophthalmol. 2006, 244, 1283. [CrossRef] [PubMed]

140. Wagner, S.K.; Jolly, J.K.; Pefkianaki, M.; Gekeler, F.; Webster, A.R.; Downes, S.M.; Maclaren, R.E. Transcorneal electrical stimulation for the treatment of retinitis pigmentosa: Results from the TESOLAUK trial. BMJ open Ophthalmol. 2017, 2, e000096. [CrossRef] [PubMed] 